Article

\title{
The Role of Magmatic and Hydrothermal Fluids in the Formation of the Sasa Pb-Zn-Ag Skarn Deposit, Republic of Macedonia
}

\author{
Sabina Strmić Palinkaš ${ }^{1, *}$, Zlatko Peltekovski ${ }^{2}$, Goran Tasev ${ }^{3}$, Todor Serafimovski ${ }^{3}$, \\ Danijela Šmajgl ${ }^{4}$, Kristijan Rajič ${ }^{1,5}{ }^{\oplus}$, Jorge E. Spangenberg ${ }^{6}$, Kai Neufeld ${ }^{1}$ and \\ Ladislav Palinkaš 5 \\ 1 Department of Geosciences, Faculty of Sciences and Technology, UiT The Arctic University of Norway in \\ Tromsø, N-9037 Tromsø, Norway; kristijan.rajic@gmail.com (K.R.); kai.neufeld@uit.no (K.N.) \\ 2 Mine SASA DOO, Rudarska u. 28, MK-2304 Makedonska Kamenica, Republic of Macedonia; \\ z.peltekovski@sasa.com.mk \\ 3 Institute of Geology, Faculty of Natural and Technical Sciences, University Goce Delcev, MK-2000 Stip, \\ Republic of Macedonia; goran.tasev@ugd.edu.mk (G.T.); todor.serafimovski@ugd.edu.mk (T.S.) \\ 4 Thermo Fisher Scientific, 28199 Bremen, Germany; danijela.smajgl@thermofisher.com \\ 5 Department of Geology, Faculty of Science, University of Zagreb, HR-10000 Zagreb, Croatia; \\ lpalinkas@geol.pmf.hr \\ 6 Institute of Earth Surface Dynamics, Geopolis, University of Lausanne, CH-1015 Lausanne, Switzerland; \\ jorge.spangenberg@unil.ch \\ * Correspondence: sabina.s.palinkas@uit.no; Tel.: +47-77-625-177
}

Received: 10 October 2018; Accepted: 15 November 2018; Published: 29 November 2018

check for updates

\begin{abstract}
The Sasa Pb-Zn-Ag deposit belongs to the group of distal base metal skarn deposits. The deposit is located within the Serbo-Macedonian massif, a metamorphosed crystalline terrain of Precambrian to Paleozoic age. The mineralization, hosted by Paleozoic marbles, shows a strong lithological control. It is spatially and temporally associated with the calc-alkaline to shoshonitic post-collisional magmatism that affected the Balkan Peninsula during the Oligocene-Miocene time period and resulted in the formation of numerous magmatic-hydrothermal ore deposits. The mineralization at the Sasa $\mathrm{Pb}-\mathrm{Zn}-\mathrm{Ag}$ deposit shows many distinctive features typical for base metal skarn deposits including: (1) a carbonate lithology as the main immediate host of the mineralization; (2) a close spatial relation between the mineralization and magmatic bodies of an intermediate composition; (3) a presence of the prograde anhydrous Ca-Fe-Mg-Mn-silicate and the retrograde hydrous $\mathrm{Ca}-\mathrm{Fe}-\mathrm{Mg}-\mathrm{Mn} \pm \mathrm{Al}$-silicate mineral assemblages; (4) a deposition of base metal sulfides, predominately galena and sphalerite, during the hydrothermal stage; and (5) a post-ore stage characterized by the deposition of a large quantity of carbonates. The relatively simple, pyroxene-dominated, prograde mineralization at the Sasa $\mathrm{Pb}-\mathrm{Zn}$-Ag skarn deposit represents a product of the infiltration-driven metasomatism which resulted from an interaction of magmatic fluids with the host marble. The prograde stage occurred under conditions of a low water activity, low oxygen, sulfur and $\mathrm{CO}_{2}$ fugacities and a high $\mathrm{K}^{+} / \mathrm{H}^{+}$molar ratio. The minimum pressure-temperature (P-T) conditions were estimated at $30 \mathrm{MPa}$ and $405^{\circ} \mathrm{C}$. Mineralizing fluids were moderately saline and low density $\mathrm{Ca}-\mathrm{Na}$-chloride bearing aqueous solutions. The transition from the prograde to the retrograde stage was triggered by cooling of the system below $400{ }^{\circ} \mathrm{C}$ and the resulting ductile-to-brittle transition. The brittle conditions promoted reactivation of old (pre-Tertiary) faults and allowed progressive infiltration of ground waters and therefore increased the water activity and oxygen fugacity. At the same time, the lithostatic to hydrostatic transition decreased the pressure and enabled a more efficient degassing of magmatic volatiles. The progressive contribution of magmatic $\mathrm{CO}_{2}$ has been recognized from the retrograde mineral paragenesis as well as from the isotopic composition of associated carbonates. The retrograde mineral assemblages,
\end{abstract}


represented by amphiboles, epidote, chlorites, magnetite, pyrrhotite, quartz and carbonates, reflect conditions of high water activity, high oxygen and $\mathrm{CO}_{2}$ fugacities, a gradual increase in the sulfur fugacity and a low $\mathrm{K}^{+} / \mathrm{H}^{+}$molar ratio. Infiltration fluids carried $\mathrm{MgCl}_{2}$ and had a slightly higher salinity compared to the prograde fluids. The maximum formation conditions for the retrograde stage are set at $375{ }^{\circ} \mathrm{C}$ and $200 \mathrm{MPa}$. The deposition of ore minerals, predominantly galena and sphalerite, occurred during the hydrothermal phase under a diminishing influence of magmatic $\mathrm{CO}_{2}$. The mixing of ore-bearing, $\mathrm{Mg}$-Na-chloride or $\mathrm{Fe}^{2+}$-chloride, aqueous solutions with cold and diluted ground waters is the most plausible reason for the destabilization of metal-chloride complexes. However, neutralization of relatively acidic ore-bearing fluids during the interaction with the host lithology could have significantly contributed to the deposition. The post-ore, carbonate-dominated mineralization was deposited from diluted $\mathrm{Ca}-\mathrm{Na}$-Cl-bearing fluids of a near-neutral $\mathrm{pH}$ composition. The corresponding depositional temperature is estimated at below $300^{\circ} \mathrm{C}$.

Keywords: Sasa Pb-Zn-Ag deposit; skarn; magmatic-hydrothermal ore deposits; fluid inclusions; stable isotopes; EBSD; Serbo-Macedonian massif; postcollisional magmatism

\section{Introduction}

Although skarn deposits represent products of interaction of a silicate melt (proximal skarns) or magmatic fluids (distal skarns) with a carbonate rich lithology, hydrothermal fluids play a significant role in evolution of all types of skarn deposits. Late hydrothermal overprints particularly affect the skarn deposit geometry, type of alteration products and ore distribution [1-4].

The Sasa Pb-Zn-Ag deposit is a typical distal skarn deposit and has been selected as a site to study processes that involve transport of base metals by magmatic and hydrothermal fluids as well as physicochemical factors that control the deposition of base metal-bearing mineral phases. The Sasa deposit $\left(42.0^{\circ} \mathrm{N}, 22.5^{\circ} \mathrm{E}\right)$ is located on the Balkan Peninsula, approximately $150 \mathrm{~km}$ east from Skopje, Republic of Macedonia (Figure 1). It consists of three ore-bearing localities: Svinja Reka, Golema Reka and Kozja Reka (Figure 2a). The deposit hosts approximately 23.4 million metric tons of ore at 7.5\% of $\mathrm{Pb}$ and $\mathrm{Zn}$ and up to $22 \mathrm{~g} / \mathrm{t} \mathrm{Ag}$. Mining activities in the area date back to ancient times. The first geological investigations began in the 19th century and industrial production started in 1966. Since November 2017, the deposit is operated by Central Asia Metals.

The Sasa Pb-Zn-Ag skarn deposit is hosted by the Serbo-Macedonian massif, a large elongate basement complex situated along the eastern part of the Balkan Peninsula. It extends southward from Serbia through Kosovo, Macedonia and Bulgaria to the Chalkidiki Peninsula in northern Greece (Figure 1) and holds numerous economically important ore deposits of $\mathrm{Cu}, \mathrm{Au}, \mathrm{Pb}$ and $\mathrm{Zn}$ (e.g., Bor and Majdanpek, Serbia; Toranica, Sasa and Bucim, Macedonia; Osogovo, Bulgaria; Skouries, Greece [5-9]).

The Sasa deposit is spatially and temporally associated with the Tertiary calc-alkaline magmatism [10]. It comprises prograde and retrograde mineral assemblages hosted by a sequence of Paleozoic marbles intercalated with quartz-graphite schists [11]. The prograde mineralization is represented by anhydrous Ca-Fe-Mn-silicate minerals (pyroxenes and pyroxenoids). A subsequent retrograde stage contains amphiboles, epidote, chlorites and ilvaite [12]. The principal ore minerals, galena and sphalerite, are accompanied by variable amounts of hydrothermal quartz and carbonates.

This study presents the mineral chemistry, fluid inclusion and stable isotope data obtained on the skarn and hydrothermal mineral assemblages to give an insight into the evolution of the mineralizing fluids, to constrain the physiochemical conditions during the skarn formation and ore deposition and to refine the metallogenic model of the deposit. 


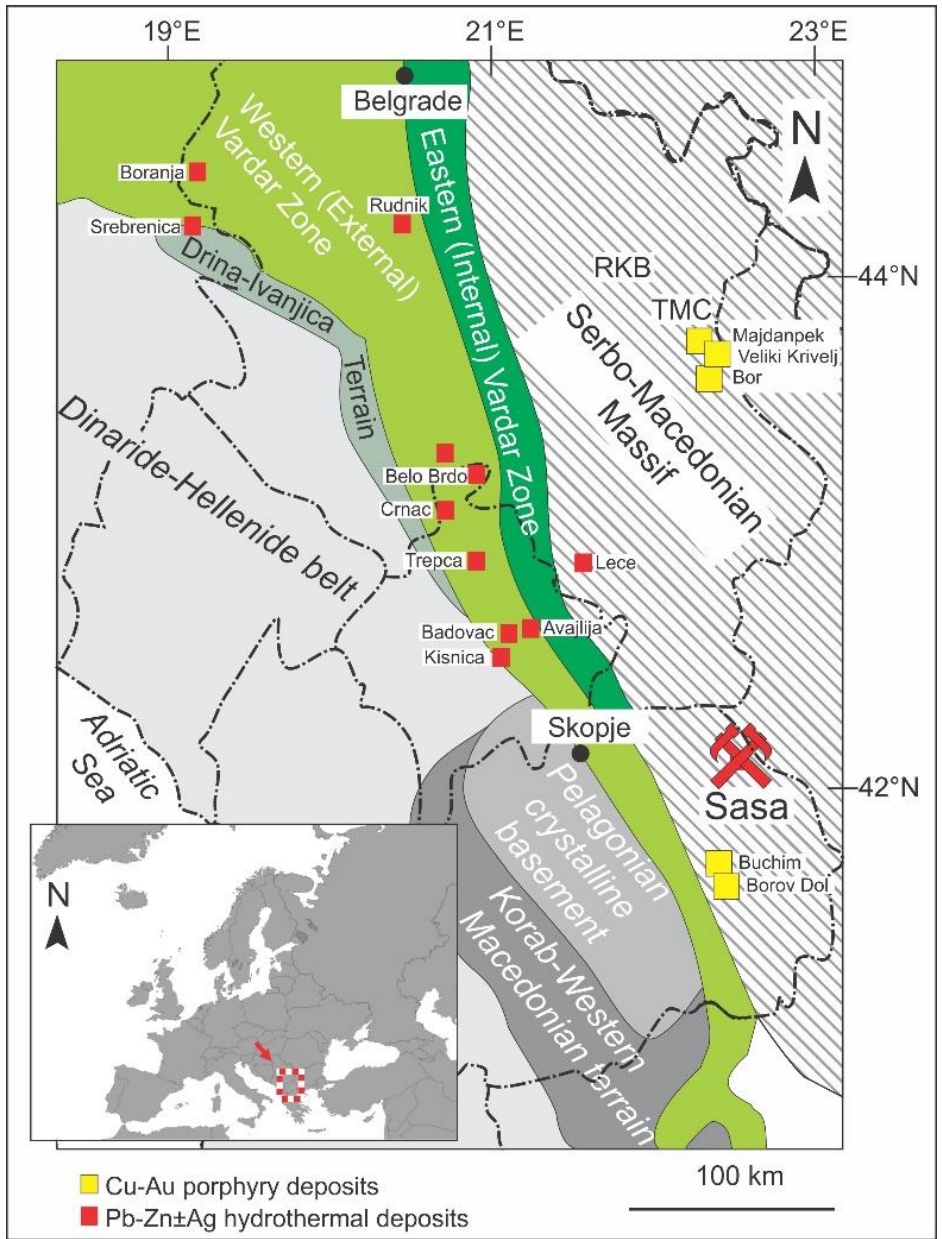

Figure 1. Regional geologic setting of the Sasa $\mathrm{Pb}-\mathrm{Zn}-\mathrm{Ag}$ skarn deposit, Republic of Macedonia, within the Balkan Peninsula (according to $[13,14]$ ). The locations of the most prominent $\mathrm{Pb}-\mathrm{Zn} \pm \mathrm{Ag}$ hydrothermal and $\mathrm{Cu}$-Au porphyry deposits are also marked. Abbreviations: $\mathrm{RKB}=$ Ridanj-Krepoljin belt, TMC = Timok magmatic complex.

\section{Geological Setting}

\subsection{Regional Geology}

The Serbo-Macedonian massif is a N-S trending crystalline belt outcropping between the Vardar ophiolite zone in the west and the Rhodope massif in the east (Figure 1). This Precambrian to Paleozoic terrain consists of two main tectonostratigraphic units, the Lower unit (also known as the Lower complex in Serbia and Macedonia, the Ograzhden unit in Bulgaria and the Vertiskos unit in Greece) and the Upper unit (the Vlasina unit in Serbia and Macedonia or the Morava unit in Bulgaria), usually distinguished by their metamorphic grade. The Lower unit was metamorphosed up to medium- to lower-amphibolite facies metamorphism, whereas the Upper unit underwent greenschist facies conditions [13-16]. The Lower unit is composed predominately of gneisses, micaschists, quartzites, amphibolites, and occasionally marbles and migmatites. This unit has been considered as a metamorphosed volcano-sedimentary sequence formed in the late Neoproterozoic to the earliest Cambrian along the active margin of north Gondwana that underwent the amphibolite facies metamorphism during the Variscan orogeny $[13,17,18]$. In contrast, the Upper unit is mostly composed of the late Neoproterozoic ocean floor sediments and igneous rocks, overlaid by a Lower Ordovician to Lower Carboniferous sedimentary sequence metamorphosed to various schists, phyllites, quartzites and marbles $[13,19,20]$. 
In the Cretaceous to Tertiary period, the Serbo-Macedonian massif as well as the adjunct Vardar zone were affected by considerable magmatic activity related to the Alpine orogeny and post-collisional collapse of the Alpine orogen, followed by extension of the Pannonian (Miocene) and Aegean areas (Eocene-Pliocene) [21-24]. The magmatism had an intermediate, mostly andesitic to trachytic, character and resulted in the formation of numerous ore deposits including porphyry $\mathrm{Cu}-\mathrm{Mo}-\mathrm{Au}$ and subordinate epithermal gold deposits (e.g., Bor, Majdanpek and Veliki Krivelj in Serbia; Buchim and Borov Dol in Macedonia; Skouries [8,9,25-28]) and Pb-Zn-Ag hydrothermal deposits (e.g., Srebrenica in Bosnia and Herzegovina; Cer and Boranja in Serbia; Trepca, Crnac and Belo Brdo in Kosovo; Sasa, Toranica and Zletovo in Macedonia; Olympias in Greece; [29-35], Figure 1a). The age of magmatism decreases from approximately $84 \mathrm{Ma}$ in the north to $19 \mathrm{Ma}$ in the southernmost part of the Serbo-Macedonian massif [36,37].

\subsection{Geology of the Deposit}

The Sasa Pb-Zn-Ag skarn deposit is hosted by a Paleozoic metamorphic complex composed of marble horizons intercalated with quartz-graphite schist and surrounded by Precambrian gneiss (Figure 2). The cross-section through the Pb-Zn-Ag Sasa skarn deposit reflects the strong lithological control on ore deposition revealing that carbonate rich lithology, i.e. marble, was almost completely replaced by the mineralization whereas other country rocks, including schists, gneisses and magmatic rocks, are mostly barren (Figure 2). The mineralized strata dip at approximately $35^{\circ}$ to south-west and range in thickness from $2 \mathrm{~m}$ to $30 \mathrm{~m}$. Rare lenses of preserved marble are characterized by a uniform calcite grain size and fine intercalations of grey mica, classifying this marble to the cipollino marble variety (Figure 3a). The dark, medium grained and foliated quartz-graphite schist consists predominately of graphite, quartz and minor sericite (Figure $3 b, c)$. The Precambrian gneiss is strongly foliated, with ductile deformed chlorite and quartz grains and brittle deformed amphiboles (Figure 3d). The mineralization is spatially associated with magmatic rocks (Figure 2), mostly of trachytic to trachydacitic composition (Figure 3e,f) and the K/Ar age is between $31 \mathrm{Ma}$ and $24 \mathrm{Ma}$ [38,39]. A relatively high $87 \mathrm{Sr} / 86 \mathrm{Sr}$ ratio $(0.7095-0.7113$, [38]) suggests a significant crustal contamination common for the Oligocene-Miocene calc-alkaline to shoshonitic post-collisional magmatism of the Balkan Peninsula [40,41]. Although the mineralization is lithologically controlled, old structures, reactivated during the Tertiary post-collisional extension, might have played a significant role in emplacement of magmatic bodies (Figure 2).

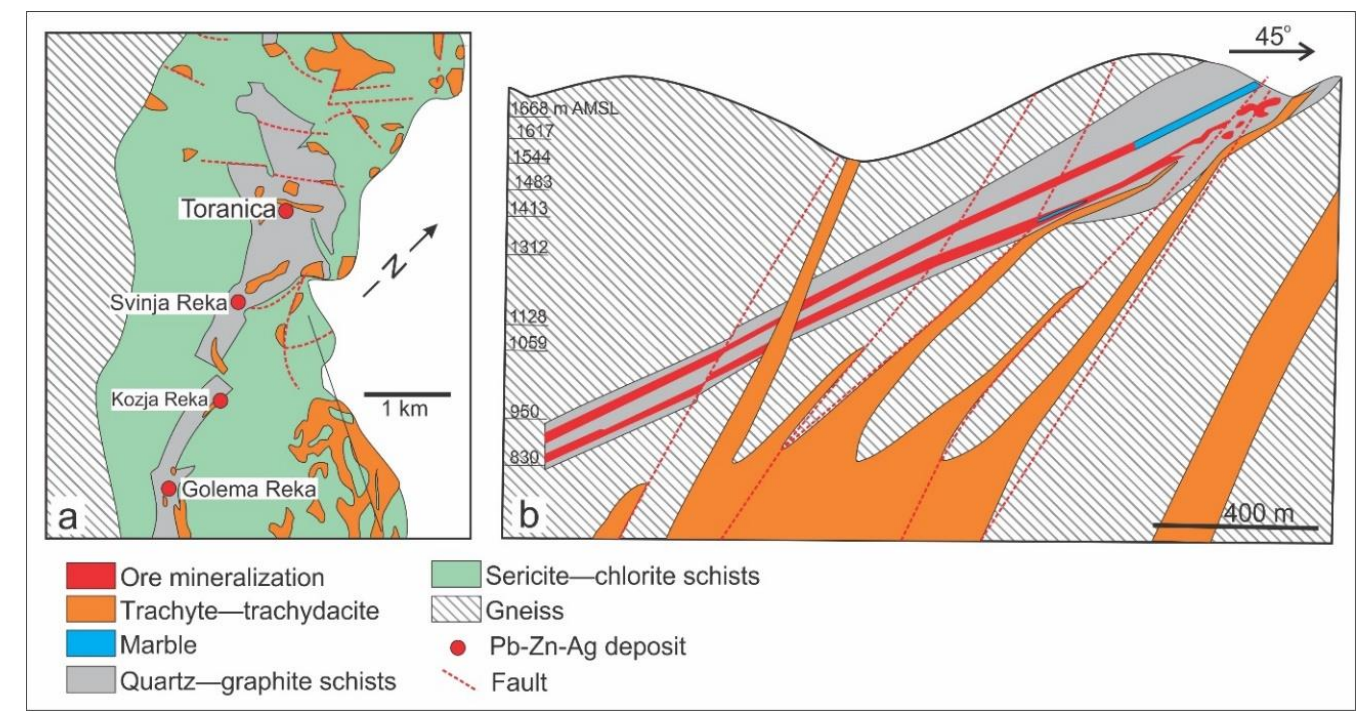

Figure 2. (a) Geologic map of the Sasa Pb-Zn-Ag skarn deposit area; (b) Longitudinal section through the Svinja Reka locality (from [39]). Abbreviation: AMSL — above mean sea level. 
The mineralization consists of skarn and hydrothermal parageneses. The skarn parageneses are characterized by the presence of Mn-enriched calc-silicate minerals, including pyroxenes, pyroxenoids, garnets, epidote, chlorites and ilvaite. The hydrothermal parageneses are mostly superimposed onto the skarn assemblages, and contain galena, sphalerite and pyrite, as well as minor pyrrhotite, chalcopyrite and magnetite. Carbonates and quartz are the most abundant gangue minerals.

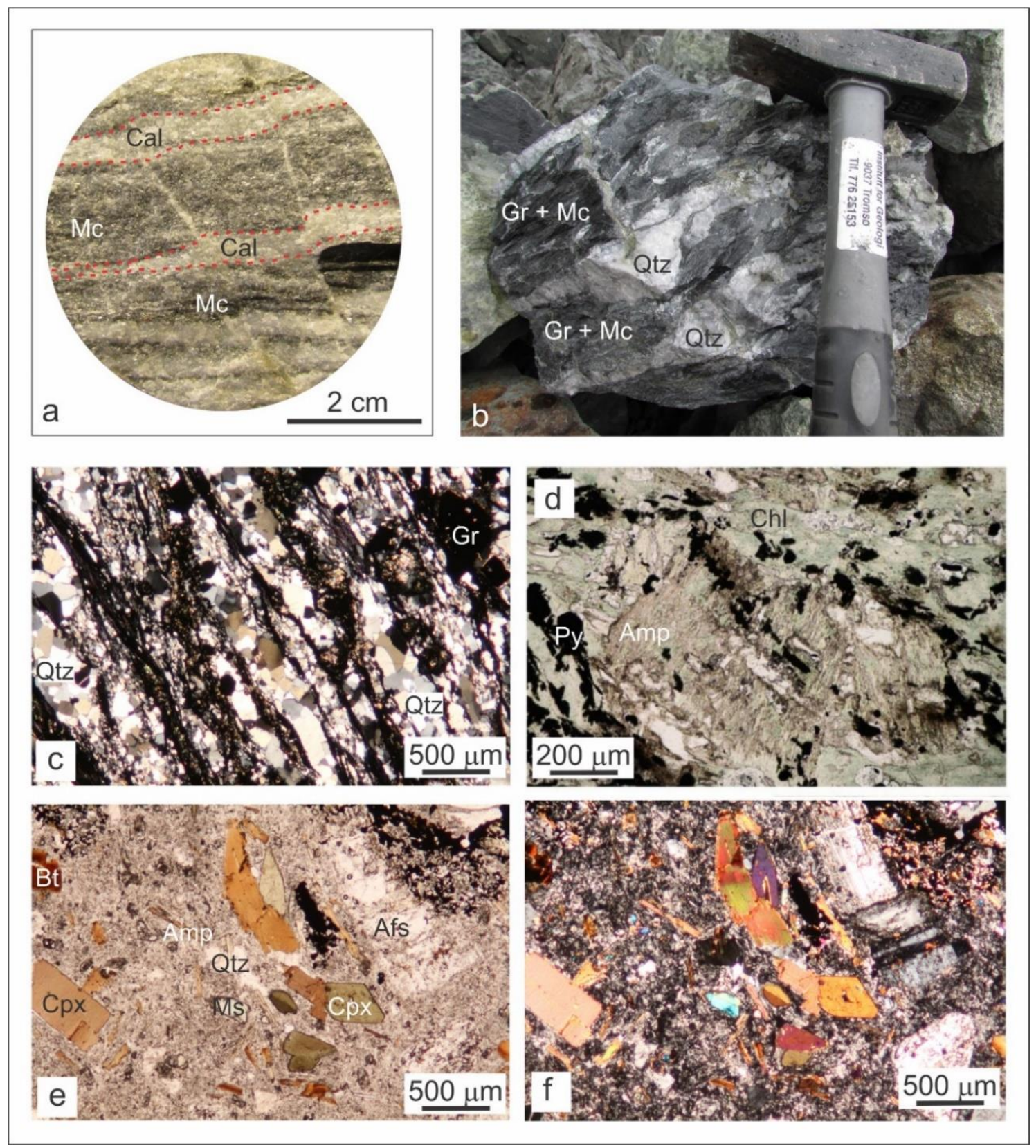

Figure 3. (a) Cross-cut section of a core drilled through cipollino marble; (b) Hand specimen of quartz-graphite schist; (c) Transmitted light photomicrograph of quartz-graphite schist (cross polars); (d) Transmitted light photomicrograph of Precambrian gneiss (plane polarized light); (e) Transmitted light photomicrograph of trachyte associated with the Sasa $\mathrm{Pb}-\mathrm{Zn}$-Ag mineralization (plane polarized light); (f) Transmitted light photomicrograph of trachyte associated with the Sasa $\mathrm{Pb}-\mathrm{Zn}$-Ag mineralization (crossed polars). Abbreviations: Cal—calcite; Mc-mica; Qtz-quartz; $\mathrm{Gr}$-graphite; Amp-amphiboles; Chl—chlorites; Py—pyrite; Cpx-clinopyroxene; Bt—biotite; Ms-muscovite; Afs—alkali feldspars. 


\section{Materials and Methods}

A total of 30 samples were collected from the Svinja Reka locality, an active underground mine at the Sasa deposit. The representative samples of host rocks, associated magmatic rocks and ore mineralization were selected for further mineralogical and geochemical studies.

Paragenetic relationships were studied in thin polished sections by transmitted and reflected polarized light microscopy. The X-ray powder diffraction (XRD) was conducted at the University of Zagreb on a Philips PW 3040/60 X'Pert PRO powder diffractometer $(45 \mathrm{kV}, 40 \mu \mathrm{A})$, with $\mathrm{CuK} \alpha$-monochromatized radiation $(\lambda=1.54056 \AA)$ and $\theta-\theta$ geometry. The area between $4^{\circ}$ and $63^{\circ} 2 \theta$, with $0.02^{\circ}$ steps, was measured with a $0.5^{\circ}$ primary beam divergence. Compound identifications were based on a computer program $X^{\prime}$ Pert high score of $1.0 \mathrm{~B}$ and literature data.

The textural features and semi-quantitative analyses of mineralized samples were examined by a Zeiss Merlin Compact VP field emission Scanning Electron Microscope (SEM) equipped with an Energy-Dispersive X-Ray (EDX) spectrometer and an Electron Backscattered Diffraction (EBSD) detector at UiT The Arctic University of Norway. EDX analyses were conducted with an X-Max80 EDX detector by Oxford instruments at a working distance of $8.5 \mathrm{~mm}$, using an accelerating voltage of $20 \mathrm{kV}$ and an aperture of $60 \mu \mathrm{m}$. The samples were mechanically polished and carbon-coated. The retrieved data were further processed by applying the AZtec software also provided by Oxford instruments. EBSD analyses for phase identification and distribution were conducted on a Nordlys EBSD detector in combination with the Aztec data processing software, both provided by Oxford instruments. The analyzed samples were mechanically and chemically polished with a colloidal silica solution and coated with a carbon layer. The samples were tilted to $70^{\circ}$. An acceleration voltage of $20 \mathrm{kV}$ was applied in combination with a $240 \mu \mathrm{m}$ aperture. Step sizes for EBSD mapping were from $4.5 \mu \mathrm{m}$ to $6 \mu \mathrm{m}$; six bands were detected with refined accuracy as indexing mode. Indexing rates were from $74.0 \%$ to $88.4 \%$. A camera exposure time of $21 \mathrm{~ms}$ was applied in both cases.

Petrographic and microthermometric measurements of fluid inclusions within transparent minerals (quartz, calcite, sphalerite and pyroxene) were performed at the University of Zagreb and at UiT The Arctic University of Norway. Double polished, $0.1 \mathrm{~mm}$ to $0.3 \mathrm{~mm}$ thick, transparent mineral wafers were studied. Measurements were carried out on Linkam THMS 600 stages mounted on an Olympus BX 51 (University of Zagreb) and an Olympus BX 2 (UiT) using 10× and 50× Olympus long-working distance objectives. Two synthetic fluid inclusion standards (SYN FLINC; pure $\mathrm{H}_{2} \mathrm{O}$ and mixed $\mathrm{H}_{2} \mathrm{O}-\mathrm{CO}_{2}$ ) were used to calibrate the equipment. The precision of the system was $\pm 2.0^{\circ} \mathrm{C}$ for homogenization temperatures, and $\pm 0.2{ }^{\circ} \mathrm{C}$ in the temperature range between $-60^{\circ}$ and $+10^{\circ} \mathrm{C}$. Microthermometric measurements were made on carefully defined fluid inclusion assemblages, representing groups of inclusions that were trapped simultaneously. The fluid inclusion assemblages were identified based on petrography prior to heating and freezing. If all of the fluid inclusions within the assemblage showed similar homogenization temperature, the inclusions were assumed to have trapped the same fluid and to have not been modified by leakage or necking; these fluid inclusions thus record the original trapping conditions [42-44].

Carbon and oxygen isotope analyses of calcite separated from the host marble, as well as from skarn and hydrothermal mineral associations, were performed at the University of Lausanne and at UiT The Arctic University of Norway. In both laboratories, calcite powder was extracted from hand-picked samples using a dentist's drill. A mass of $250 \mu \mathrm{g}$ of powder was loaded in sealed reaction vessels, then flushed with helium gas and reacted at $72{ }^{\circ} \mathrm{C}$ with phosphoric acid. The evolved carbon dioxide was sampled using a ThermoFinnigan Gas-Bench and isotope ratios were measured in continuous flow mode using a ThermoFinnigan Delta + XP mass spectrometer. Data was extracted to an EXCEL file by using the ISODAT NT EXCEL export utility and further calculation steps were carried out using a predefined EXCEL Worksheet. Linearity corrections were applied based on the relationships between the intensity of the first sample peak $(m / z 44)$ and $\delta^{18}$ O value of the standards. Due to calibration based directly on standard, which were part of each run (Carrara marble), correction for calcite runs was unnecessary. The stable carbon and oxygen isotope ratios are reported in the delta (notation as 
per mil (\%) deviation relative to the Vienna Standard Mean Ocean Water (V-SMOW) for oxygen and Vienna Pee Dee Belemnite (V-PDB) for carbon. The analytical reproducibility was better than $\pm 0.05 \%$ for $\delta{ }^{13} \mathrm{C}$ and $\pm 0.1 \%$ for $\delta{ }^{18} \mathrm{O}$.

\section{Results}

\subsection{Petrography}

The paragenetic sequence of the Sasa Pb-Zn-Ag skarn deposit (Figure 4) illustrates that the mineralization was deposited as a result of several mineralizing events, similar to other skarn deposits worldwide [45-47]. Marble layers represent the main immediate host rock, and they are usually completely replaced by the mineralization. Textural features of the skarn parageneses, including rhythmic banding, scalloping and fingering, reflect infiltration-driven replacement as the main mechanism of their formation (Figure 5, [48]). The prograde stage has an anhydrous character with prevailing $\mathrm{Ca}-\mathrm{Fe}-\mathrm{Mn}$ pyroxenes and minor pyroxenoids and garnets. Pyroxenes form fibroradial aggregates (Figure 5). The retrograde stage resulted in a complex mineral assemblage that consists of a mixture of amphiboles, ilvaite, epidote, chlorites, magnetite, pyrrhotite, carbonates and quartz. It texturally mimics the fibroradial texture inherited from the prograde mineralization (Figure 5). The superimposed hydrothermal mineral assemblages predominantly occur as replacements and open-space fillings. They contain galena, sphalerite, pyrite and minor chalcopyrite, as well as syn-ore and post-ore gangue carbonates and quartz (Figure 6).

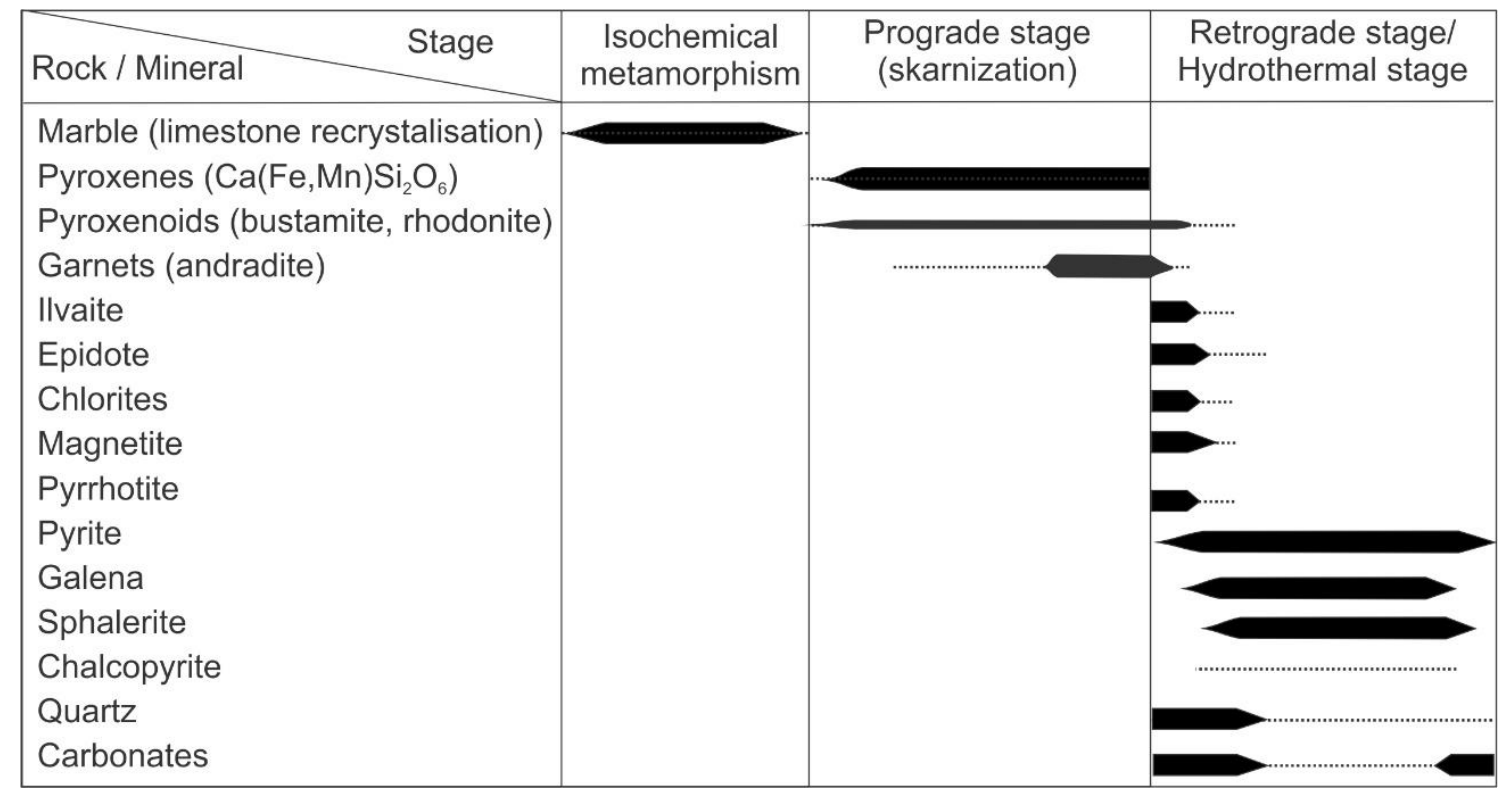

Figure 4. Paragenetic sequence of the Sasa $\mathrm{Pb}-\mathrm{Zn}-\mathrm{Ag}$ skarn deposit. 


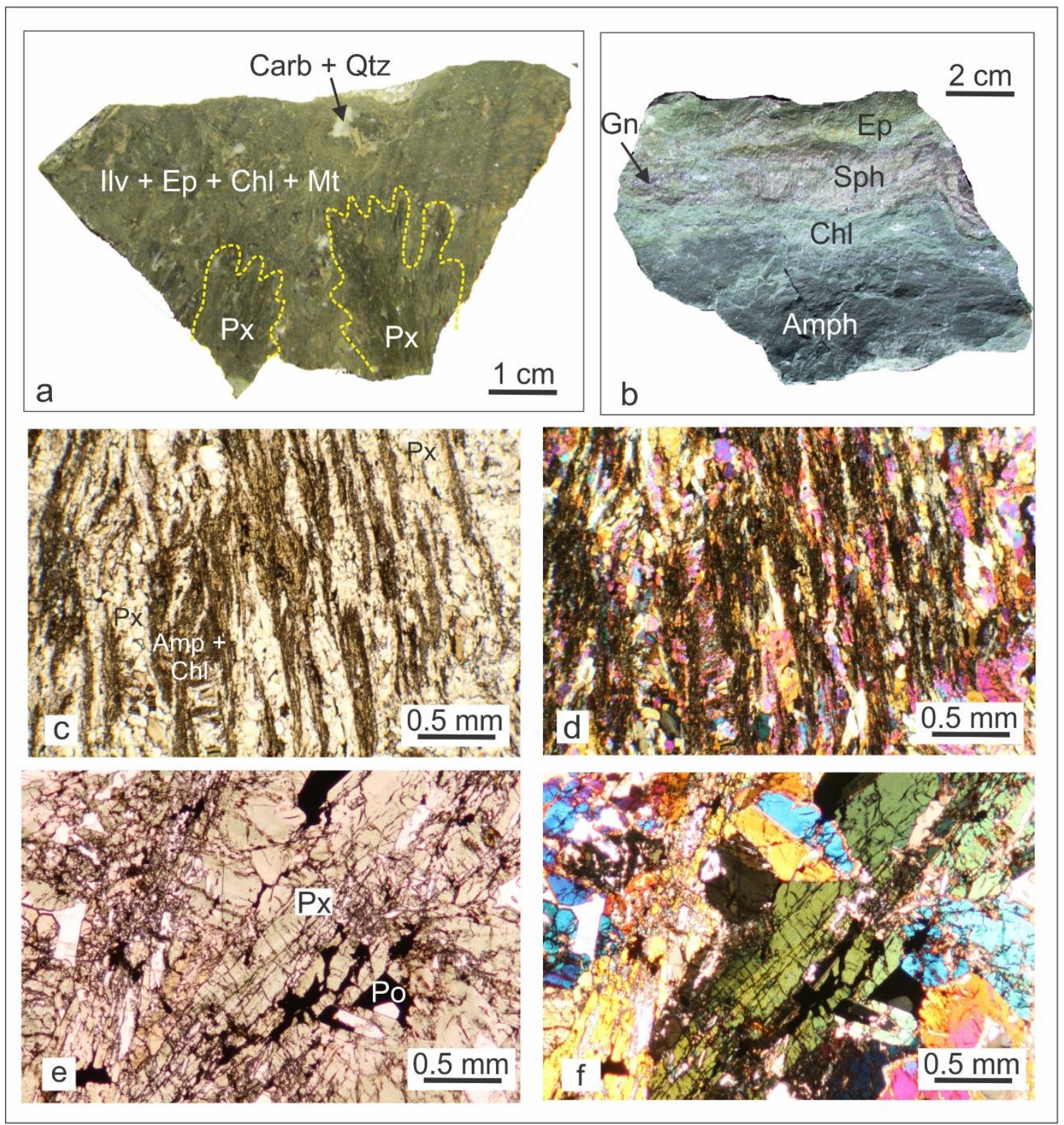

Figure 5. (a) Hand-specimen showing the transition from the prograde (anhydrous silicate-dominated) stage to the retrograde (hydrous silicate- dominated) stage; (b) Hand-specimen showing the rhythmic bedding of the retrograde/hydrothermal mineral paragenesis; (c) Transmitted light photomicrograph of the retrograde mineralization mimicking prograde fibroradial texture (plane polarized light); (d) Transmitted light photomicrograph of the retrograde mineralization mimicking prograde fibroradial texture (crossed polars); (e) Transmitted light photomicrograph of prograde pyroxene partly replaced by pyrrhotite (plane polarized light); (f) Transmitted light photomicrograph of prograde pyroxene partly replaced by pyrrhotite (crossed polars). Abbreviations: Px-pyroxene; Amph-Amphibole; Chl—chlorite; Sph—Sphalerite; Ep—epidote; Po—pyrrhotite; Py-Pyrite. 


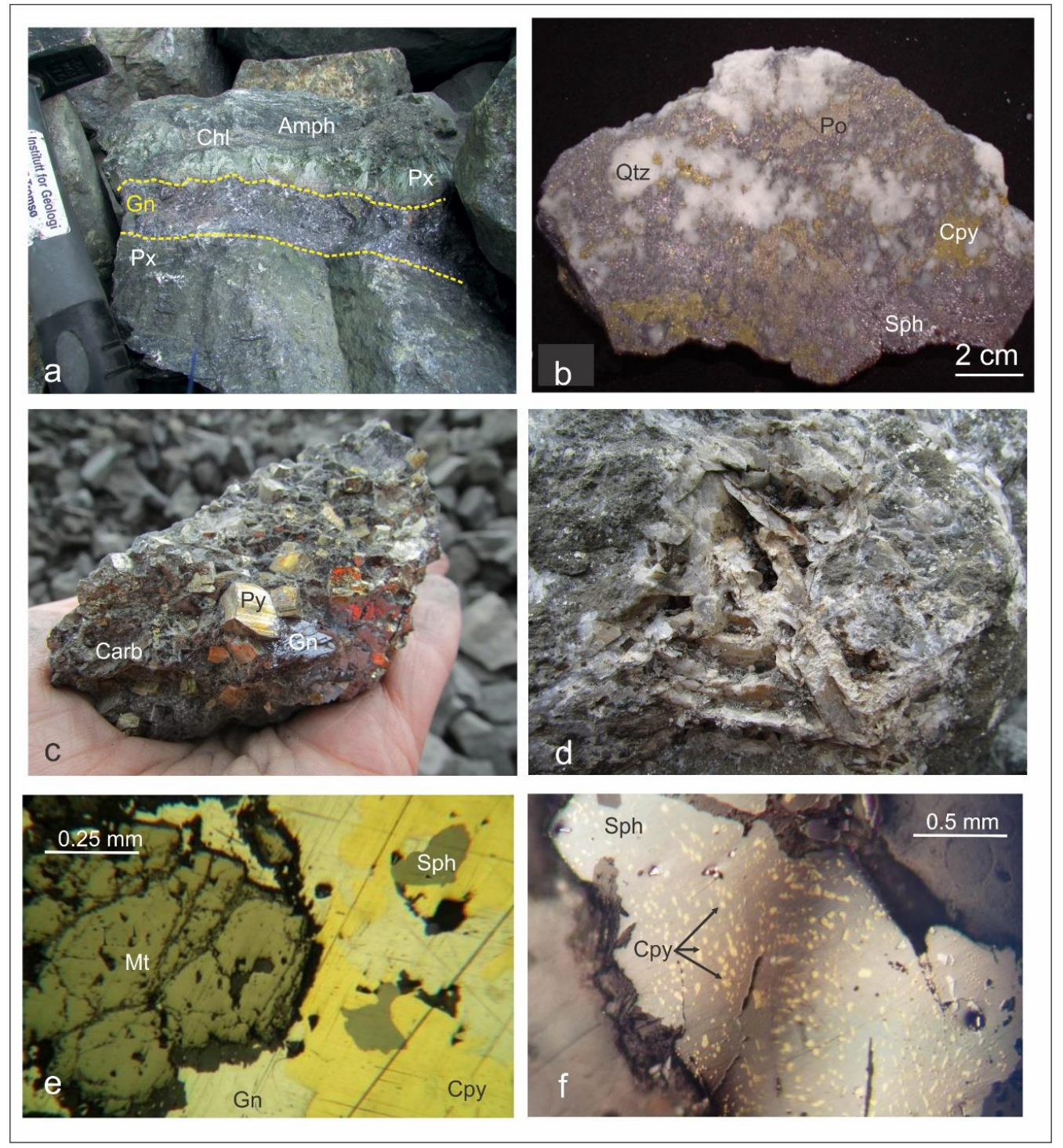

Figure 6. (a) The rhythmic banding of the prograde mineralization with the retrograde and hydrothermal mineral parageneses suggests that replacement processes were important mechanisms for the development of retrograde alterations, as well as for deposition of the hydrothermal mineralization; (b) Hand-specimen showing a typical hydrothermal paragenesis composed of pyrrhotite, chalcopyrite, sphalerite and quartz; (c) Hand-specimen consisting of pyrite, galena and carbonates reflects the open-space deposition of the hydrothermal mineralization; (d) Post-ore bladed calcite; (e) Reflected light photomicrograph of hydrothermal mineral paragenesis consisting of magnetite, chalcopyrite, galena and sphalerite; (f) Reflected light photomicrograph showing chalcopyrite disease in Fe-rich sphalerite. This texture is often interpreted as a diffusion-controlled replacement of the Fe-rich sphalerite mostly along crystal planes or controlled by compositional variabilities within the sphalerite. Abbreviations: Px-pyroxene; Amph—Amphibole; Chl—chlorite; Gn—Galena; Sph-Sphalerite; Cpy-Chalcopyrite; Po-Pyrrhotite; Mt—Magnetite; Qtz-Quartz; Carb-Carbonates.

\subsection{X-ray Diffraction (XRD)}

Hydrothermally altered skarn assemblages are characterized by very fine-grained textures that preclude determination of their mineral composition by optical microscopy techniques and, alternatively, the XRD method was applied. The representative XRD patterns presented in Figure 7 suggest that prograde mineral assemblages composed mostly of pyroxenes from the hedenbergite-johannsenite series, which are altered to amphiboles from the actinolite-ferroactinolite 
series, serpentine, minerals from the epidote group, chlorites of the clinochlore type, magnetite, carbonates and quartz. In addition, ore minerals, including pyrite, galena, sphalerite and chalcopyrite, have been recorded.
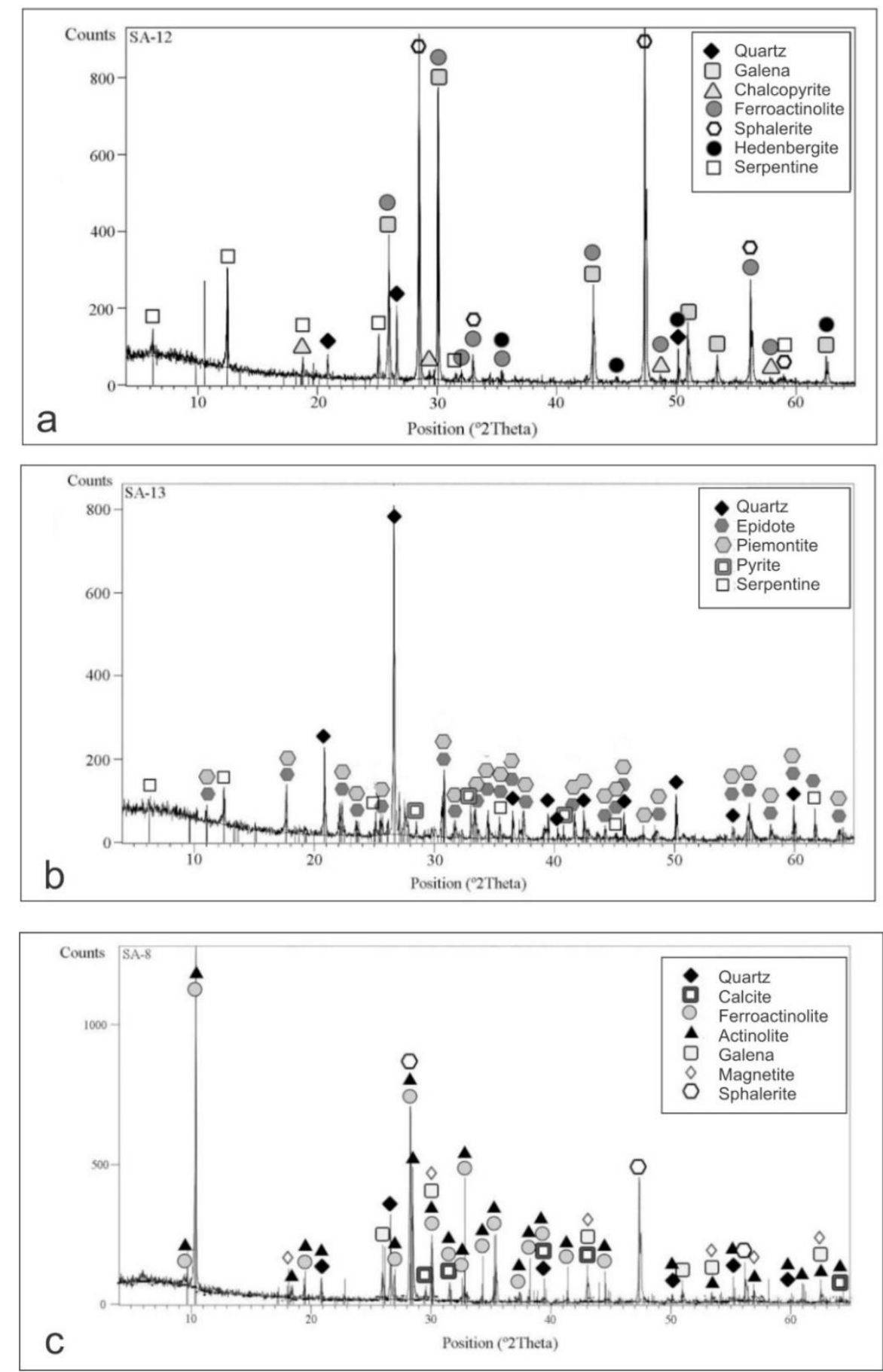

Figure 7. Representative X-ray Diffraction (XRD) patterns reveal a complex mineral composition of retrograde alterations: (a) Prograde pyroxene (hedenbergite) partly altered to a mixture of ferroactinolite and serpentine and overprinted by the hydrothermal mineralization composed of galena, chalcopyrite and quartz; (b) Completely altered prograde mineralization into a mixture of epidote, piemontite and serpentine. Hydrothermal pyrite and quartz are also present; (c) Completely altered prograde mineralization into a mixture of ferroactinolite, actinolite, magnetite, carbonate and quartz. Galena and sphalerite have been recorded as well. 


\subsection{Electron Back Scattered Diffraction (EBSD)}

The EBSD method was utilized to determine the spatial distribution of retrograde alteration products. The EBSD maps presented in Figures 8 and 9 suggest that prograde pyroxenes have been altered to various degrees during the infiltration of hydrothermal fluids. Sharp alteration zones composed of a mixture of hydrous calc-silicate minerals, predominantly amphiboles, chlorites, epidote and ilvaite point to an increase in water activity (Figure 8). In contrast, mixtures of quartz and carbonates usually overprint individual pyroxene grains, mimicking the prograde fibroradial texture and reflecting an increase in the $\mathrm{CO}_{2}$ fugacity (Figure 9). Carbonates from both the calcite and dolomite groups have been identified. Fine grained sulfide minerals suggest an increase in the sulfur fugacity.

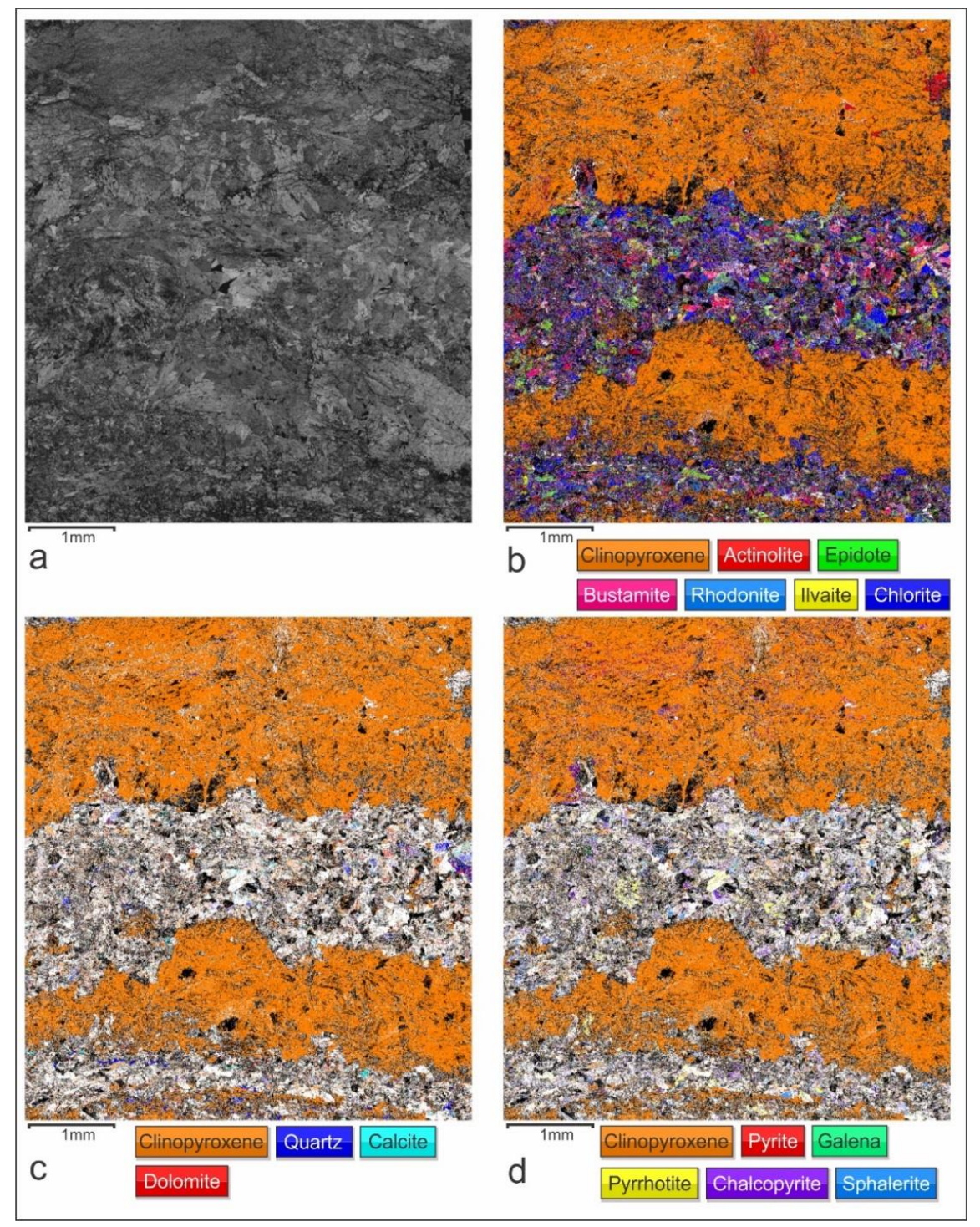

Figure 8. The Electron Back Scattered Diffraction (EBSD) maps illustrating the retrograde alterations of prograde pyroxene under high water activity: (a) Band contrast EBSD map; (b) Distribution of prograde clinopyroxene and retrograde hydrous silicates; (c) Distribution of prograde clinopyroxene and retrograde/hydrothermal carbonates and quartz; (d) Distribution of prograde clinopyroxene and hydrothermal sulfide mineralization. The EBSD mapping step size was $4.5 \mu \mathrm{m}$ and the indexing rate was $74.0 \%$. 


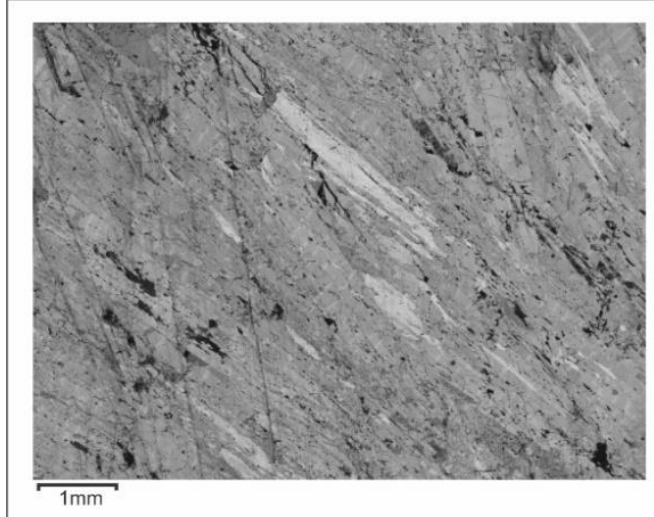

a
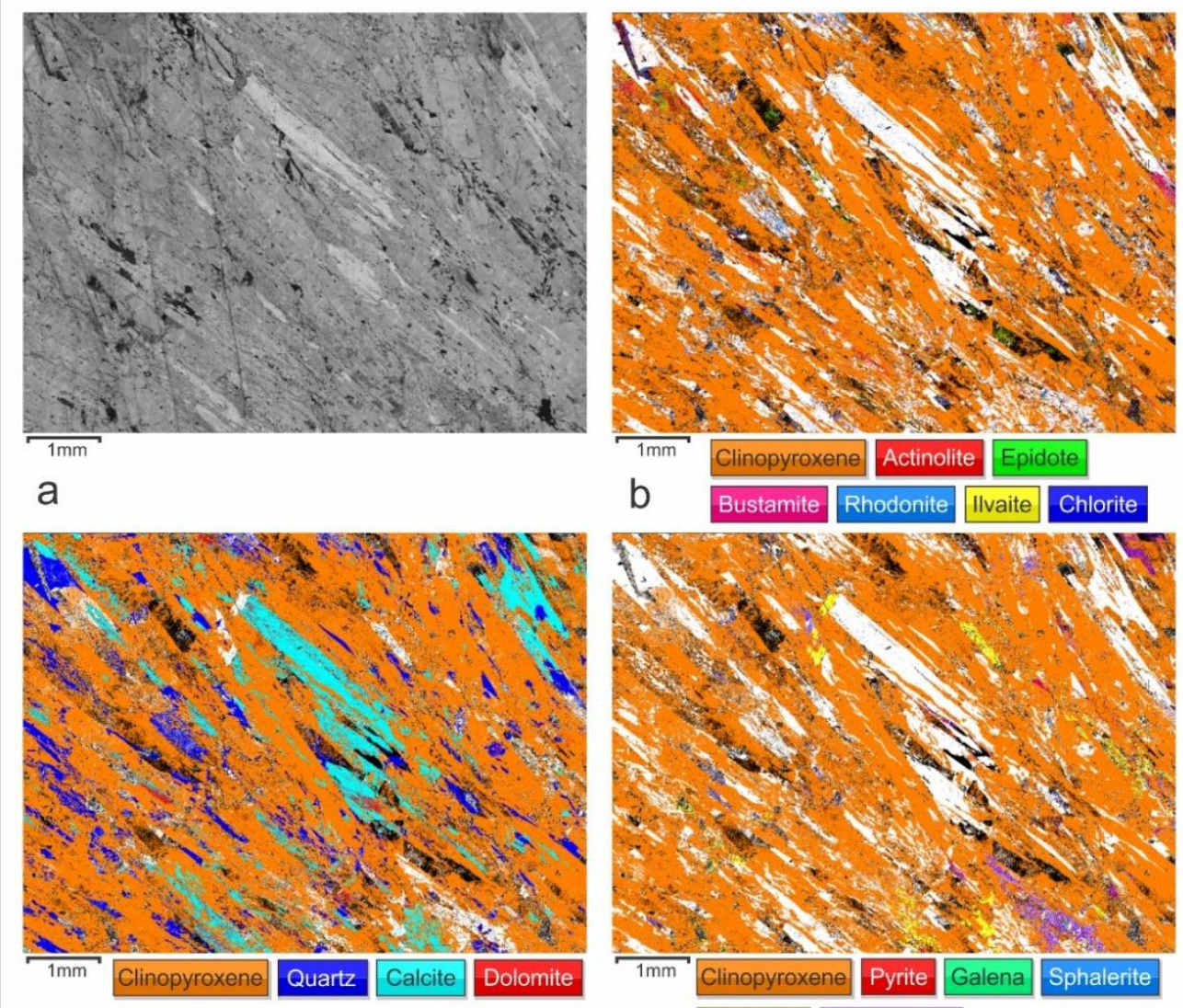

C

d Pyrrhotite Chalcopyrite

Figure 9. The EBSD maps illustrating the retrograde alterations of prograde pyroxene under an increased $\mathrm{CO}_{2}$ fugacity: (a) Band contrast EBSD map; (b) Distribution of prograde clinopyroxene and retrograde hydrous silicates; (c) Distribution of prograde clinopyroxene and retrograde/hydrothermal carbonates and quartz; (d) Distribution of prograde clinopyroxene and hydrothermal sulfide mineralization. The EBSD mapping step size was $6 \mu \mathrm{m}$ and the indexing rate was $88.4 \%$.

\subsection{Mineral Chemistry}

The major element composition of pyroxenes, analyzed by the EDS/SEM technique, is listed in Table 1 and plotted in the diopside-johannsenite-hedenbergite ternary diagram (Figure 10). Hedenbergite, with $74-80 \mathrm{~mol} \%$, represents the main pyroxene constituent. The johannsenite content varies between $16-21 \mathrm{~mol} \%$ and diopside between 1-6 mol \%.

The EDS/SEM analyses of sulfides revealed that sphalerite owes its black color to an enrichment of iron (>10 wt. \% of Fe, Table 2). Sphalerite also contains detectable amounts of cadmium, manganese and copper (Table 2). Galena carries significant amounts of bismuth (up to $4.7 \mathrm{wt}$. \% of Bi). Indium and silver have been detected as well (Table 2). Variations in the trace element content of sphalerite and galena are presented in Figure 11. 
Table 1. Chemical composition of pyroxenes from the Sasa Pb-Zn-Ag skarn deposit. Hd-hedenbergite; Jo-johannsenite; Di-diopside.

\begin{tabular}{|c|c|c|c|c|c|c|c|c|c|}
\hline Sample & Point & $\mathrm{CaO}$ & $\mathrm{FeO}$ & $\mathrm{MnO}$ & $\mathrm{MgO}$ & $\mathrm{SiO}_{2}$ & Hd & Jo & Di \\
\hline & & & & wt. \% & & & & $\%$ & \\
\hline \multirow[t]{10}{*}{ SA-101 } & $P x-1$ & 24.6 & 22.2 & 5.1 & 0.5 & 47.6 & 79.8 & 18.4 & 1.8 \\
\hline & $P x-2$ & 25.1 & 20.5 & 4.3 & 1.1 & 49.0 & 79.1 & 16.5 & 4.4 \\
\hline & $P x-3$ & 24.4 & 21.8 & 4.7 & 0.8 & 48.3 & 79.8 & 17.2 & 3.0 \\
\hline & $P x-4$ & 22.8 & 21.2 & 5.6 & 1.0 & 49.4 & 76.3 & 20.1 & 3.7 \\
\hline & Px-5 & 25.0 & 21.2 & 5.7 & 0.7 & 47.5 & 77.0 & 20.6 & 2.4 \\
\hline & $P x-6$ & 24.0 & 22.8 & 5.1 & 0.7 & 47.4 & 79.7 & 17.9 & 2.4 \\
\hline & Px-7 & 23.2 & 19.7 & 4.9 & 0.8 & 51.5 & 77.5 & 19.5 & 3.0 \\
\hline & $P x-8$ & 23.1 & 21.2 & 6.0 & 0.8 & 49.0 & 75.7 & 21.3 & 3.0 \\
\hline & $P x-9$ & 23.9 & 20.2 & 5.2 & 1.0 & 49.6 & 76.4 & 19.8 & 3.8 \\
\hline & Px-10 & 22.7 & 19.1 & 5.2 & 1.6 & 51.5 & 73.9 & 20.1 & 6.0 \\
\hline \multirow[t]{10}{*}{ SA-102 } & Px-11 & 25.2 & 21.1 & 5.2 & 0.6 & 47.9 & 78.6 & 19.2 & 2.1 \\
\hline & $P x-12$ & 25.4 & 19.8 & 5.3 & 0.7 & 48.8 & 76.8 & 20.5 & 2.8 \\
\hline & $P x-13$ & 25.4 & 18.9 & 5.3 & 0.7 & 49.6 & 75.7 & 21.4 & 2.9 \\
\hline & Px-14 & 23.9 & 21.2 & 5.6 & 0.4 & 48.8 & 77.9 & 20.4 & 1.6 \\
\hline & Px-15 & 24.0 & 21.0 & 5.5 & 0.4 & 49.1 & 78.2 & 20.4 & 1.3 \\
\hline & $P x-16$ & 24.6 & 20.4 & 4.6 & 0.9 & 49.4 & 78.9 & 17.8 & 3.4 \\
\hline & Px-17 & 23.4 & 20.3 & 4.6 & 1.6 & 50.1 & 76.5 & 17.5 & 5.9 \\
\hline & Px-18 & 23.0 & 22.8 & 5.3 & 1.0 & 48.0 & 78.4 & 18.1 & 3.4 \\
\hline & Px-19 & 24.6 & 19.8 & 5.0 & 0.7 & 49.9 & 77.3 & 19.7 & 2.9 \\
\hline & $P x-20$ & 22.5 & 19.8 & 5.4 & 0.7 & 51.6 & 76.6 & 20.8 & 2.5 \\
\hline
\end{tabular}

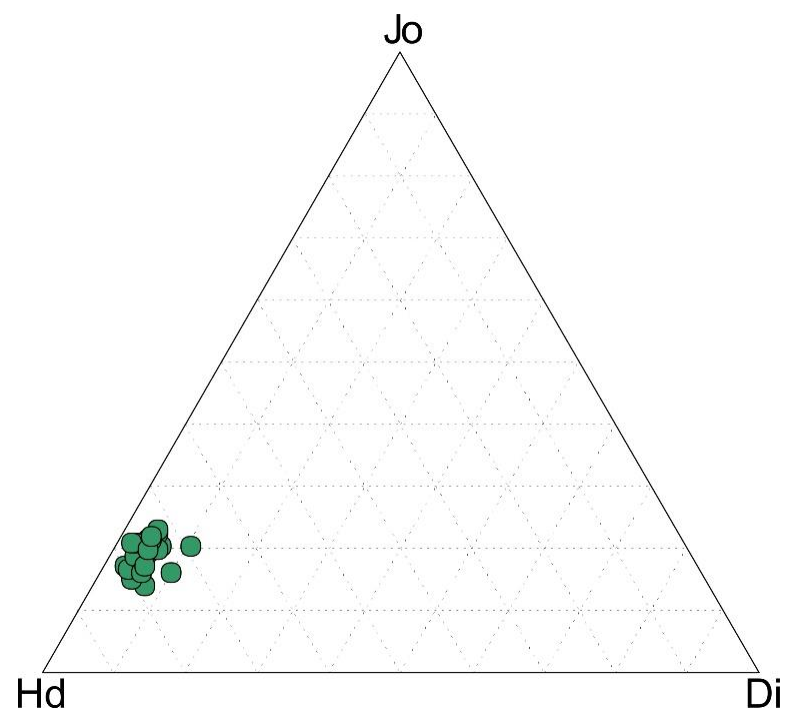

Figure 10. Jo-Di-Hd (Mn-Mg-Fe) ternary diagram showing compositional variations of pyroxenes from the Sasa $\mathrm{Pb}-\mathrm{Zn}-\mathrm{Ag}$ skarn deposit. End members are $\mathrm{Di}=$ diopside, $\mathrm{Hd}=$ hedenbergite, and Jo = johannsenite.
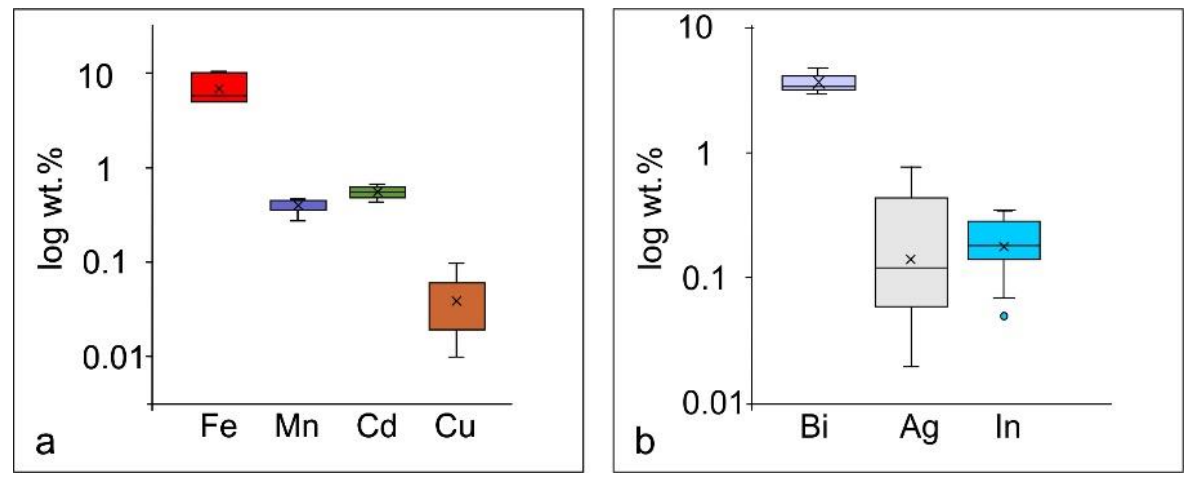

Figure 11. Variations in the trace element content of (a) Sphalerite; (b) Galena from the Sasa Pb-Zn-Ag skarn deposit. 
Table 2. Semi-quantitative composition of sulfides from the Sasa Pb-Zn-Ag skarn deposit. $n$ —number of point analyses per sample; <d.1.—below detection limit; STD—standard deviation.

\begin{tabular}{|c|c|c|c|c|c|c|c|}
\hline Sample & Mineralogy & $n$ & Element & Minimum & Maximum & Mean & STD \\
\hline Sasa-17 & Galena & 7 & & \multicolumn{4}{|c|}{ wt. $\%$} \\
\hline & & & $\mathrm{Pb}$ & 77.76 & 82.26 & 80.23 & 1.52 \\
\hline & & & $\mathrm{Bi}$ & 4.02 & 4.69 & 4.36 & 0.23 \\
\hline & & & $\mathrm{Ag}$ & 0.02 & 0.62 & 0.16 & 0.21 \\
\hline & & & In & 0.15 & 0.31 & 0.21 & 0.06 \\
\hline & & & S & 12.12 & 12.57 & 12.37 & 0.18 \\
\hline & & & Total & 94.30 & 99.22 & 97.33 & 1.69 \\
\hline \multirow[t]{8}{*}{ Sasa-17 } & Sphalerite & 4 & & & & & \\
\hline & & & $\mathrm{Zn}$ & 58.44 & 59.34 & 58.86 & 0.39 \\
\hline & & & $\mathrm{Fe}$ & 10.18 & 10.38 & 10.25 & 0.09 \\
\hline & & & $\mathrm{Mn}$ & 0.28 & 0.34 & 0.32 & 0.03 \\
\hline & & & $\mathrm{Cd}$ & 0.43 & 0.58 & 0.51 & 0.08 \\
\hline & & & $\mathrm{Cu}$ & $<$ d.l. & $<$ d.l. & & \\
\hline & & & $\mathrm{S}$ & 28.37 & 28.93 & 28.62 & 0.26 \\
\hline & & & Total & 97.85 & 99.55 & 98.56 & 0.79 \\
\hline \multirow[t]{7}{*}{ Sasa-20 } & Galena & 11 & & & & & \\
\hline & & & $\mathrm{Pb}$ & 83.12 & 84.75 & 83.96 & 0.59 \\
\hline & & & $\mathrm{Bi}$ & 2.97 & 3.55 & 3.25 & 0.19 \\
\hline & & & $\mathrm{Ag}$ & $<$ d.l. & 0.77 & 0.36 & 0.27 \\
\hline & & & In & $<$ d.l. & 0.28 & 0.12 & 0.08 \\
\hline & & & S & 12.48 & 12.69 & 12.55 & 0.07 \\
\hline & & & Total & 99.33 & 101.13 & 100.25 & 0.59 \\
\hline \multirow[t]{8}{*}{ Sasa-20 } & Sphalerite & 12 & & & & & \\
\hline & & & $\mathrm{Zn}$ & 57.56 & 59.95 & 58.85 & 0.92 \\
\hline & & & $\mathrm{Fe}$ & 5.11 & 5.83 & 5.47 & 0.34 \\
\hline & & & $\mathrm{Mn}$ & 0.43 & 0.47 & 0.45 & 0.01 \\
\hline & & & $\mathrm{Cd}$ & 0.45 & 0.66 & 0.55 & 0.07 \\
\hline & & & $\mathrm{Cu}$ & $<$ d.l. & 59.92 & 5.01 & 17.29 \\
\hline & & & $\mathrm{S}$ & 32.15 & 32.73 & 32.51 & 0.21 \\
\hline & & & Total & 96.53 & 98.89 & 97.88 & 0.81 \\
\hline \multirow[t]{7}{*}{ Sasa-24 } & Galena & 7 & & & & & \\
\hline & & & $\mathrm{Pb}$ & 82.06 & 83.73 & 82.87 & 0.56 \\
\hline & & & $\mathrm{Bi}$ & 3.15 & 3.85 & 3.44 & 0.24 \\
\hline & & & $\mathrm{Ag}$ & 0.03 & 0.14 & 0.09 & 0.04 \\
\hline & & & In & 0.16 & 0.35 & 0.28 & 0.07 \\
\hline & & & S & 12.36 & 12.55 & 12.44 & 0.08 \\
\hline & & & Total & 98.47 & 100.25 & 99.11 & 0.68 \\
\hline \multirow[t]{8}{*}{ Sasa-24 } & Sphalerite & 4 & & & & & \\
\hline & & & $\mathrm{Zn}$ & 55.21 & 57.95 & 56.39 & 1.17 \\
\hline & & & $\mathrm{Fe}$ & 9.76 & 10.48 & 10.02 & 0.32 \\
\hline & & & $\mathrm{Mn}$ & 0.35 & 0.43 & 0.39 & 0.03 \\
\hline & & & $\mathrm{Cd}$ & 0.58 & 0.63 & 0.61 & 0.02 \\
\hline & & & $\mathrm{Cu}$ & $<$ d.l. & 0.10 & 0.03 & 0.08 \\
\hline & & & $S$ & 30.21 & 31.19 & 30.49 & 0.47 \\
\hline & & & Total & 96.24 & 100.50 & 97.92 & 1.83 \\
\hline
\end{tabular}

\subsection{Fluid Inclusion Studies}

Fluid inclusions entrapped within skarn and hydrothermal minerals preserve information about mineralizing fluids in a magmatic-hydrothermal system and reveal variations of pressure-temperature-chemical composition ( $\mathrm{P}-\mathrm{T}-\mathrm{X})$ conditions over time. Fluid inclusion data collected from pyroxenes, quartz and carbonates from the Sasa $\mathrm{Pb}-\mathrm{Zn}-\mathrm{Ag}$ skarn deposit are summarized in Table 3. 
Table 3. Summary of the fluid inclusion data obtained from the Sasa $\mathrm{Pb}-\mathrm{Zn}-\mathrm{Ag}$ skarn deposit. Px—pyroxene; Qtz—quartz; Cc—calcite; F-Degree of fill; L-Liquid phase; V-Vapor phase.

\begin{tabular}{|c|c|c|c|c|c|c|}
\hline \multirow{2}{*}{$\begin{array}{c}\begin{array}{c}\text { Mineralization } \\
\text { Type }\end{array} \\
\text { Host Mineral }\end{array}$} & \multirow{2}{*}{$\begin{array}{c}\text { Prograde } \\
\mathrm{Px}\end{array}$} & \multirow{2}{*}{$\begin{array}{c}\text { Retrograde } \\
\text { Qtz }\end{array}$} & \multicolumn{4}{|c|}{ Hydrothermal } \\
\hline & & & Syn-ore Qtz & Syn-ore Qtz & Post-ore Cc & Post-ore Cc \\
\hline $\begin{array}{c}\text { Fluid Inclusion } \\
\text { Type }\end{array}$ & Primary & Primary & Primary & Secondary & Primary & Secondary \\
\hline Phases $\left(\right.$ at $\left.25^{\circ} \mathrm{C}\right)$ & $\mathrm{L}+\mathrm{V}$ & $\mathrm{L}+\mathrm{V}$ & $\mathrm{L}+\mathrm{V}$ & $\mathrm{L}+\mathrm{V}$ & $\mathrm{L}+\mathrm{V}$ & $\mathrm{L}+\mathrm{V}$ \\
\hline $\mathrm{F}\left(\right.$ at $\left.25^{\circ} \mathrm{C}\right)$ & 0.6 & $0.7-0.8$ & 0.7 & $0.8-0.9$ & $0.7-0.8$ & 0.9 \\
\hline Composition & $\begin{array}{c}\mathrm{NaCl}-\mathrm{CaCl}_{2-}- \\
\mathrm{H}_{2} \mathrm{O}\end{array}$ & $\begin{array}{c}\mathrm{NaCl}-\mathrm{MgCl}_{2}- \\
\mathrm{H}_{2} \mathrm{O}\end{array}$ & $\begin{array}{c}\mathrm{NaCl}-\mathrm{MgCl}_{2-} \\
\mathrm{H}_{2} \mathrm{O} \text { or } \mathrm{FeCl}_{2-} \\
\mathrm{H}_{2} \mathrm{O}\end{array}$ & $\begin{array}{c}\mathrm{NaCl}-\mathrm{CaCl}_{2-} \\
\mathrm{H}_{2} \mathrm{O}\end{array}$ & $\begin{array}{c}\mathrm{NaCl}-\mathrm{CaCl}_{2-} \\
\mathrm{H}_{2} \mathrm{O}\end{array}$ & $\begin{array}{c}\mathrm{NaCl}-\mathrm{CaCl}_{2-}- \\
\mathrm{H}_{2} \mathrm{O}\end{array}$ \\
\hline $\begin{array}{c}\text { Salinity } \\
\text { (wt } \% \mathrm{NaCl} \text { equ.) }\end{array}$ & 7.5-9.6 & $9.3-10.9$ & 3.9-9.1 & $4.2-6.3$ & $4.8-8.8$ & $2.2-2.9$ \\
\hline Th $\left({ }^{\circ} \mathrm{C}\right)$ & $403-433$ & $237-390$ & 240-394 & $125-239$ & $242-297$ & $130-145$ \\
\hline Density $\left(\mathrm{g} / \mathrm{cm}^{3}\right)$ & 0.5270 .598 & $0.680-0.899$ & $0.612-0.890$ & $0.852-0.966$ & $0.820-0.856$ & $0.944-0.951$ \\
\hline
\end{tabular}

Primary fluid inclusions entrapped by pyroxene are usually found in isolated clusters or along growth zones. The inclusions come in a variety of shapes, mostly elongated, squared and irregular. Their size ranges from $<2-20 \mu \mathrm{m}$. At room temperature, they contain liquid (L) and vapor $(\mathrm{V})$ phases and are characterized by a uniform degree of fill around 0.6 (Figure 12a,b). The eutectic temperature (Te) recorded near $-50{ }^{\circ} \mathrm{C}$ reveals $\mathrm{NaCl}$ and $\mathrm{CaCl}_{2}$ as the principal dissolved salts [49]. The final ice melting temperature in the range between $-6.3^{\circ} \mathrm{C}$ and $-4.7^{\circ} \mathrm{C}$ corresponds to the salinity between $7.5-9.6$ wt. \% NaCl equ. [50]. Homogenization to liquid phase was obtained between $403-433{ }^{\circ} \mathrm{C}$. The calculated bulk density spans from $0.527-0.598 \mathrm{~g} / \mathrm{cm}^{3}$. Secondary inclusions occur along healed fractures. Their size of $<2 \mu \mathrm{m}$ precludes reliable microthermometric measurements.

Quartz associated with retrogradely altered skarn assemblages hosts visible primary fluid inclusions. Primary fluid inclusions occur within clusters. They are mostly rounded or of irregular shape and range in size up to $20 \mu \mathrm{m}$. At room temperature, these types of inclusions contain liquid and vapor phases (Figure 12c). The eutectic temperature around $-31^{\circ} \mathrm{C}$ indicates that the mineralizing fluids were enriched in $\mathrm{MgCl}_{2}$ [49]. The final ice melting temperature between $-7.5^{\circ} \mathrm{C}$ and $-6.1^{\circ} \mathrm{C}$ corresponds to the apparent salinity between 9.3-10.9 wt. \% $\mathrm{NaCl}$ equ. [50]. Homogenization to liquid phase was recorded in the wide temperature range from $237-390^{\circ} \mathrm{C}$.

Syn-ore quartz entrapped primary fluid inclusions mostly along its growth zones. The inclusions are two-phase ( $\mathrm{L}$ and $\mathrm{V}$ ), have irregular shapes and their size varies up to $25 \mu \mathrm{m}$. The degree of fill is estimated around 0.7 (Figure 12d). The eutectic temperature around $-35{ }^{\circ} \mathrm{C}$ suggests a $\mathrm{MgCl}_{2}-\mathrm{NaCl}-\mathrm{H}_{2} \mathrm{O}$ or $\mathrm{FeCl}_{2}-\mathrm{H}_{2} \mathrm{O}$ system [49]. The final ice melting temperature between $-2.3^{\circ} \mathrm{C}$ and $-5.9^{\circ} \mathrm{C}$ points to the apparent salinity between 3.9-9.1 wt. \% $\mathrm{NaCl}$ equiv. The total homogenization by the vapor phase disappearance is recorded in the temperature interval between $240-394{ }^{\circ} \mathrm{C}$. The calculated fluid density spans from $0.665-0.858 \mathrm{~g} / \mathrm{cm}^{3}$. Secondary inclusion trails crosscut mineral grains and contain two-phase ( $\mathrm{L}$ and $\mathrm{V}$ ) inclusions of irregular shape with the degree of fill between 0.8 and 0.9 (Figure 12e). They entrapped moderate salinity fluids ( $4.2-6.3$ wt. $\% \mathrm{NaCl}$ equ.) and exhibit homogenization into the liquid phase between $125-239^{\circ} \mathrm{C}$.

The post-ore stage of the mineral parageneses is characterized by deposition of a significant amount of carbonates, predominantly calcite, and a minor amount of quartz. Primary inclusions in post-ore carbonates commonly occur in isolated clusters and show negative crystal shapes. Their size ranges from $5-50 \mu \mathrm{m}$. They contain two phases ( $\mathrm{L}$ and $\mathrm{V}$ ) and have the degree of fill between 0.7 and 0.8 (Figure 12f). Obtained microthermometric data indicate that post-ore minerals were deposited from cooler $\mathrm{CaCl}_{2}-\mathrm{NaCl}-\mathrm{H}_{2} \mathrm{O}$ solutions of moderate salinity $\left(\mathrm{Te} \approx-52{ }^{\circ} \mathrm{C}\right.$; salinity $=4.8-8.8$ wt. \% $\mathrm{NaCl}$ equiv; $\mathrm{Th}=242-297^{\circ} \mathrm{C}$ ). Rare secondary inclusions revealed that diluted and relatively cold fluids (salinity $=2.2-2.9 \mathrm{wt}$. $\% \mathrm{NaCl}$ equiv; $\mathrm{Th}=130-145^{\circ} \mathrm{C}$ ) were circulating in the area even when the mineralizing processes had terminated. 

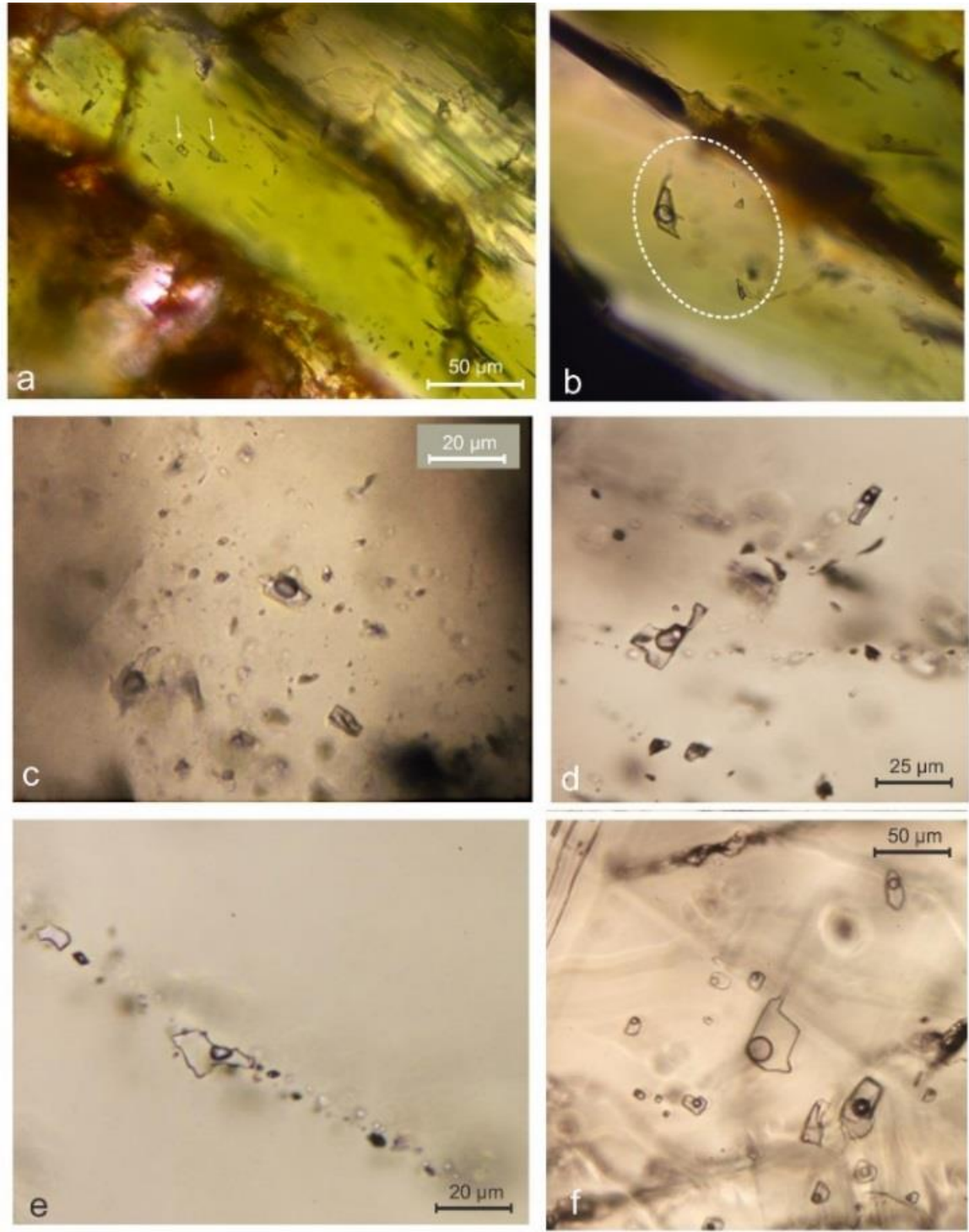

Figure 12. Photomicrographs of fluid inclusions from the Sasa Pb-Zn-Ag skarn deposit; (a) Primary two-phase (L and V) fluid inclusions hosted along growth zones of hedenbergite; (b) Isolated primary two-phase fluid inclusions in hedenbergite; (c) Primary two-phase (L and V) fluid inclusions hosted by retrograde quartz; (d) Primary fluid inclusions hosted by syn-ore quartz; (e) Trail of secondary fluid inclusions within syn-ore quartz; (f) Primary fluid inclusions hosted by post-ore calcite.

\subsection{Stable Isotope Data}

The $\delta^{13} \mathrm{C}$ and $\delta^{18} \mathrm{O}$ values obtained from different generations of calcite are listed in Table 4 and shown in Figure 13. The barren host cipollino marble has $\delta^{13} \mathrm{C}$ and $\delta^{18} \mathrm{O}$ values of $1.4 \% 0 \mathrm{~V}$-PDB and $26.3 \%$ V-SMOW, respectively. Calcite associated with skarn mineral parageneses have $\delta^{13} \mathrm{C}$ values between $-7.4 \%$ and $-7.2 \%$ V-PDB and $\delta^{18} \mathrm{O}$ values between $5.7 \%$ and $7.0 \%$ V-SMOW. Syn-ore and post-ore hydrothermal calcite exhibit mostly overlapping $\delta^{13} \mathrm{C}$ and $\delta^{18} \mathrm{O}$ values in the range between $-6.4 \%$ and $-4.1 \% 0$ V-PDB and $13.9 \%$ and $15.4 \%$ V-SMOW, respectively. 
Table 4. Carbon and oxygen isotope composition of calcite from the Sasa Pb-Zn-Ag skarn deposit. V-SMOW = Vienna Standard Mean Ocean Water. V-PDB = Vienna Pee Dee Belemnite.

\begin{tabular}{cccc}
\hline Sample & Type of Mineralization & $\boldsymbol{\delta}^{\mathbf{1 3}} \mathbf{C}(\boldsymbol{\%} \mathbf{.} \mathbf{V}-\mathbf{P D B})$ & $\mathbf{\delta}^{\mathbf{1 8}} \mathbf{O} \mathbf{( \% )} \mathbf{\text { V-SMOW) }}$ \\
\hline Sa-1-C & Cippolino marble & 1.4 & 26.3 \\
Sa-101 & Altered skarn & -7.4 & 5.7 \\
Sa-101-1 & Altered skarn & -7.3 & 6.4 \\
Sa-102 & Altered skarn & -7.2 & 7.0 \\
Sa-103 & Altered skarn & -7.3 & 6.4 \\
Sa-15 & Hydrothermal ore & -4.7 & 14.6 \\
Sa-15-2 & Hydrothermal ore & -4.8 & 14.4 \\
Sa-15-3 & Hydrothermal ore & -4.8 & 14.6 \\
Sa-16-C & Hydrothermal ore & -5.1 & 14.7 \\
Sa-17 & Hydrothermal ore & -6.0 & 14.3 \\
Sa-17-0 & Hydrothermal ore & -5.6 & 15.4 \\
Sa-17-1 & Hydrothermal ore & -5.8 & 14.7 \\
Sa-17-M1 & Hydrothermal ore & -4.1 & 13.9 \\
Sa-17-M2 & Hydrothermal ore & -4.2 & 13.9 \\
Sa-17-C & Hydrothermal ore & -5.6 & 14.7 \\
Sa-18-O & Hydrothermal ore & -6.4 & 8.3 \\
Sa-19 & Hydrothermal ore & -6.0 & 14.4 \\
Sa-19-C & Hydrothermal ore & -5.0 & 14.8 \\
\hline
\end{tabular}

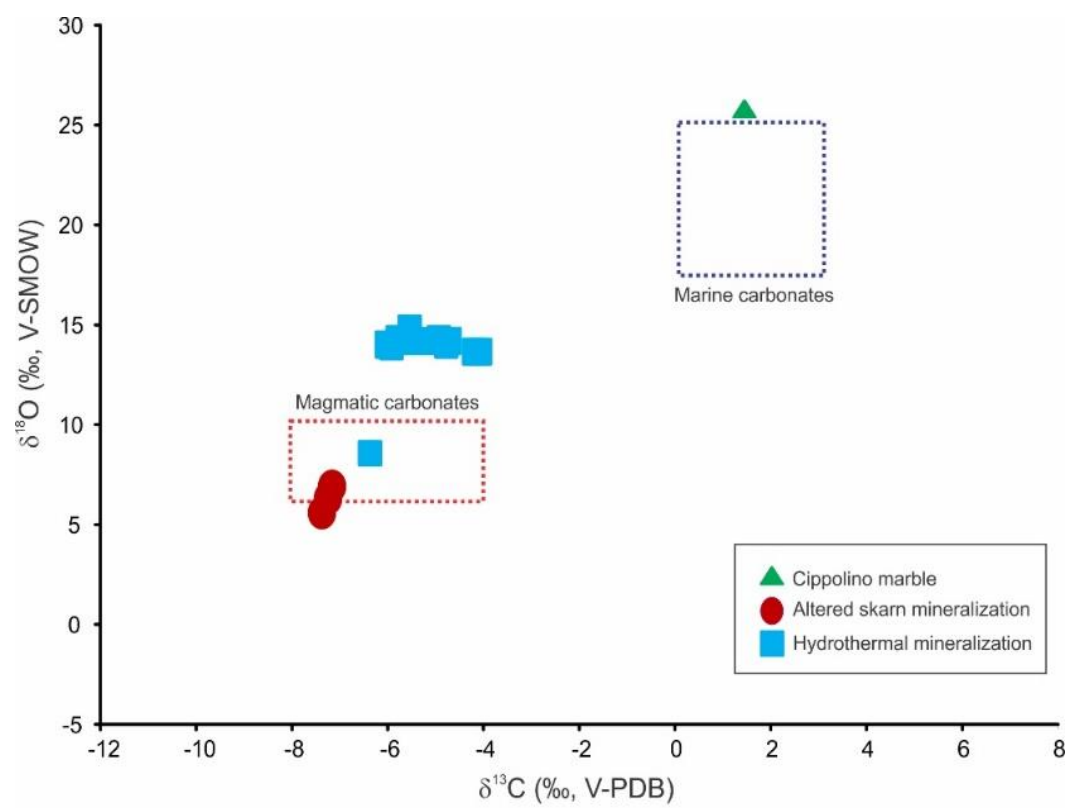

Figure 13. $\delta^{13} \mathrm{C}$ vs. $\delta^{18} \mathrm{O}$ plot of different generations of carbonates from the Sasa Pb-Zn-Ag skarn deposit. Reference values for marine carbonates reference values for magmatic carbonates from [51] and [52].

\section{Discussion}

Geological, mineralogical and geochemical features of the Sasa Pb-Zn-Ag deposit classify this deposit to the group of calcic $\mathrm{Pb}-\mathrm{Zn}$ skarn deposits [45]. Although the mineralization is closely associated with magmatic rocks, direct contacts between the mineralization and the magmatic rocks are obscure (Figure 2), suggesting a distal character of the deposit and the interaction of mineralizing fluids with the host carbonate rocks (cipollino marble) as the major mineralizing mechanism.

Geochemical features (trachytic to trachydacitic composition; calc-alkaline character; $\mathrm{Na}_{2} \mathrm{O} / \mathrm{K}_{2} \mathrm{O}$ $<1$; high large-ion lithophile element to high field strength element ratios (LILE/HFSE); strong enrichment in $\mathrm{K}, \mathrm{Pb}$ and $\mathrm{U}$ ) as well as their $\mathrm{K} / \mathrm{Ar}$ age (31-24 Ma) suggest that magmatic rocks 
associated with the Sasa deposit are a product of the calc-alkaline to shoshonitic post-collisional magmatism that affected the Balkan Peninsula during the Oligocene-Miocene period [21,23,38-41,53], resulting in the formation of numerous magmatic-hydrothermal ore deposits along the Vardar Zone and the Serbo-Macedonian Massif (Figure 1; [25-35,54]).

The paragenetic sequence (Figure 4) indicates that, during its formation, the Sasa $\mathrm{Pb}-\mathrm{Zn}-\mathrm{Ag}$ deposit underwent three main stages similar to other known skarn deposits worldwide: (1) a stage of isochemical metamorphism; (2) an anhydrous prograde stage and (3) a retrograde/hydrothermal stage $[1,55,56]$. As the deposit is hosted by a highly metamorphosed terrain, it is difficult to distinguish the regional metamorphic signature from the metamorphism associated with the emplacement of Tertiary magmatic bodies. However, the isotopic composition of preserved lenses of the host marble overlap with values typical for marine carbonates, suggesting that the metamorphism has not disturbed its primary isotopic composition.

The prograde mineral assemblage is marked by the presence of anhydrous Ca-Fe-Mg-Mn silicates, predominantly pyroxenes from the hedenbergite-johannsenite series. The predominance of anhydrous minerals reflects a low water activity, whereas the prevalence of pyroxene (hedenbergite) over garnets (andradite) suggests a high ferrous/ferric ratio and a relatively reductive environment [57]. Absence of Fe-sulfides indicates a low sulfur fugacity during the prograde stage. Although our SEM/EDS analyses (Table 1) revealed that pyroxenes are characterized by a relatively high and uniform $\mathrm{FeO} / \mathrm{MnO}$ ratio, previously published data $[12,58]$ suggest greater variations in the pyroxene composition among different ore bodies and local predomination of Mn-rich pyroxenes. The variations may be controlled by periodical variations in the chemistry of infiltrating magmatic fluids:

$$
\begin{aligned}
& \mathrm{CaCO}_{3} \text { (calcite) }+2 \mathrm{H}_{4} \mathrm{SiO}_{4}+\mathrm{Fe}^{2+} \boxminus \mathrm{CaFeSi}_{2} \mathrm{O}_{6} \text { (hedenbergite) }+3 \mathrm{H}_{2} \mathrm{O}+\mathrm{CO}_{2}+2 \mathrm{H}^{+} \\
& \mathrm{CaCO}_{3} \text { (calcite) }+2 \mathrm{H}_{4} \mathrm{SiO}_{4}+\mathrm{Mn}^{2+} \boxminus \mathrm{CaMnSi}_{2} \mathrm{O}_{6} \text { (johansennite) }+3 \mathrm{H}_{2} \mathrm{O}+\mathrm{CO}_{2}+2 \mathrm{H}^{+}
\end{aligned}
$$

and/or in local temperature oscillations:

$$
\begin{gathered}
\mathrm{CaFeSi}_{2} \mathrm{O}_{6} \text { (hedenbergite) }+\mathrm{Mn}^{2+} \boxminus \mathrm{CaMnSi}_{2} \mathrm{O}_{6} \text { (johannsenite) }+\mathrm{Fe}^{2+} \\
\mathrm{rH}_{25}{ }^{\circ} \mathrm{C}, 1 \mathrm{~atm}=-7 \mathrm{~kJ} / \mathrm{mole}^{*}
\end{gathered}
$$

* Calculated for standard conditions using thermodynamic data published by $[59,60]$.

In contrast to the carbonate component of the host cipollino marble that was replaced by pyroxenes, grey mica has not been significantly affected by metasomatic processes during the prograde stage of the mineralization, probably due to the insufficient water activity and a relatively high $\mathrm{K}^{+} / \mathrm{H}^{+}$ molar ratio:

$$
2 \mathrm{KAl}_{2}\left(\mathrm{AlSi}_{3} \mathrm{O}_{10}\right)(\mathrm{OH})_{2} \text { (kaolinite) }+3 \mathrm{H}_{2} \mathrm{O}+2 \mathrm{H}^{+} \boxminus 3 \mathrm{Al}_{2} \mathrm{Si}_{2} \mathrm{O}_{5}(\mathrm{OH})_{4}(\text { mica })+2 \mathrm{~K}^{+}
$$

According to the fluid inclusion data, the prograde stage occurred at temperatures above $405^{\circ} \mathrm{C}$ and at pressures above $30 \mathrm{MPa}$ under the influence of moderate salinity and low density $\mathrm{Ca}-\mathrm{Na}$-chloride bearing aqueous fluids. The absence of liquid $\mathrm{CO}_{2}$ indicates that $\mathrm{XCO}_{2}$ was below 0.1 [61-63]. Due to absence of any reliable independent geothermometer and/or geobarometer, only the minimum P-T conditions can be set (Figure 14).

Textural relations (Figures 5, 8 and 9) indicate that pyroxenes were replaced by mixtures of hydrous silicates, carbonates, quartz and magnetite, reflecting an increase in water activity and oxygen and/or $\mathrm{CO}_{2}$ fugacities:

$5 \mathrm{CaFeSi}_{2} \mathrm{O}_{6}$ (hedenbergite) $+\mathrm{H}_{2} \mathrm{O}+3 \mathrm{CO}_{2}(\mathrm{~g}) \boxminus \mathrm{Ca}_{2} \mathrm{Fe}_{5} \mathrm{Si}_{8} \mathrm{O}_{22}(\mathrm{OH})_{2}$ (ferroactinolite) + $3 \mathrm{CaCO}_{3}$ (calcite) $+2 \mathrm{SiO}_{2}$ (quartz) 


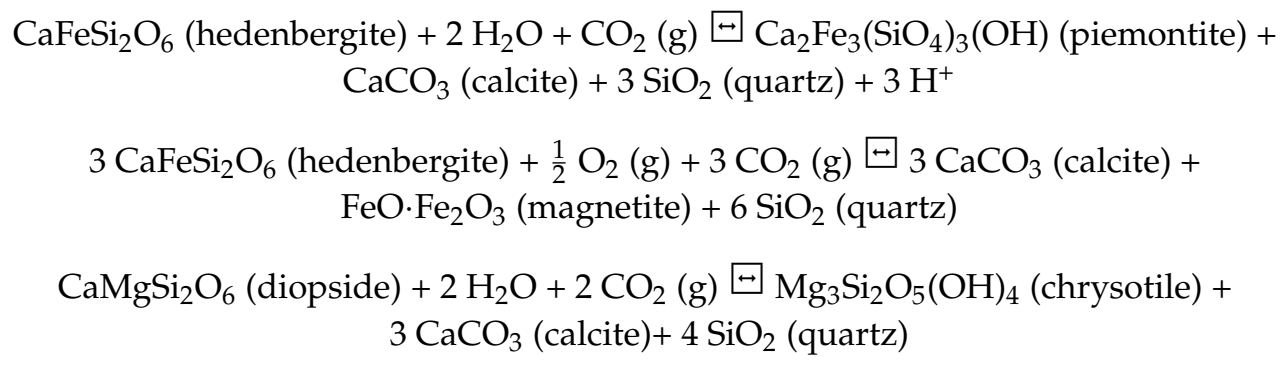

Although minerals formed during the prograde phase do not incorporate $\mathrm{Al}$, the retrograde mineral paragenesis contains aluminosilicates (mostly chlorites and epidote group minerals). The presence of carbonates points to near-neutral $\mathrm{pH}$ conditions and a limited capability for hydrothermal transport of aluminum [64]. However, layers of grey mica within the host cipollino marble might have served as a local source of $\mathrm{Al}$ :

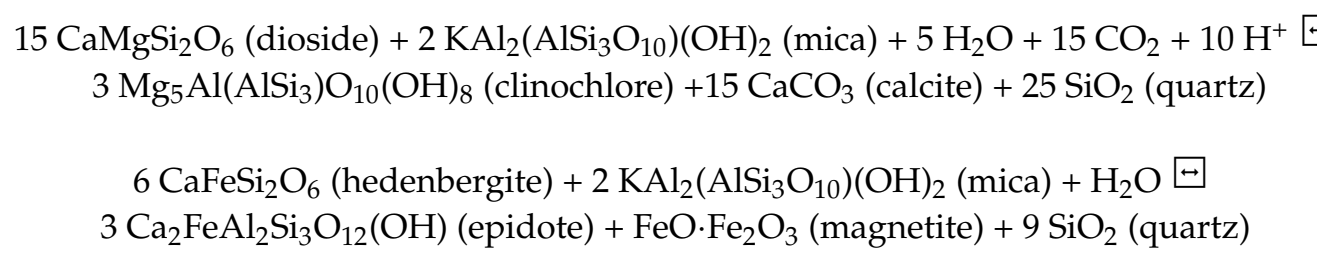

The stable isotope composition of the carbonates revealed a significant contribution of magmatic $\mathrm{CO}_{2}$ during the retrograde stage of the Sasa deposit (Figure 13). The fluid inclusion studies suggest that infiltrating fluids were $\mathrm{Mg}-\mathrm{Na}$-chloride or $\mathrm{Fe}^{2+}$-chloride solutions. Their salinities are slightly greater compared to the prograde fluids and the homogenization temperatures point to the gradual cooling of the system. The coexistence of rhodonite, rhodochrosite and quartz implies that temperature and pressure did not exceed $375{ }^{\circ} \mathrm{C}$ and $200 \mathrm{MPa}$ (Figure 14). Cooling of the system below $400{ }^{\circ} \mathrm{C}$ resulted with the ductile-to-brittle transition [65-67], promoted reactivation of old (pre-Tertiary) faults and shifted the system from the lithostatic to hydrostatic regime. Such conditions allowed progressive infiltration of ground water and therefore increased the water activity and oxygen fugacity. At the same time, due to the lithostatic to hydrostatic transition, the pressure dropped by approximately 2.7 times, triggering a more efficient degassing of the emplaced magmatic body and increasing fugacity of numerous volatiles including $\mathrm{H}_{2} \mathrm{O}, \mathrm{CO}_{2}, \mathrm{H}_{2} \mathrm{~S}$ and / or $\mathrm{SO}_{2}$. The progressive contribution of magmatic $\mathrm{CO}_{2}$ has been recognized from the retrograde mineral paragenesis (Equations (5)-(9); Figure 4), as well as from the isotopic composition of associated carbonates (Table 4; Figure 13). As Cl preferentially partitions into the fluid phase $[68,69]$, fluxes of magmatic fluids will increase the total salinity of the circulating fluids. This increase in the salinity during the retrograde stage has been recorded by fluid inclusions entrapped by retrograde quartz, i.e., quartz that crystallized as the retrograde alteration product after prograde pyroxenes (Figure 15). The greater salinity promoted the metal-chloride complexing which, together with the higher water activity in the system, enhanced the hydrothermal transport of base metals, including $\mathrm{Pb}$ and $\mathrm{Zn}$ [64], and moved the Sasa deposit to the hydrothermal ore-forming stage (Figure 4).

The retrograde stage is marked by an increase in the sulfur fugacity that resulted in a replacement of Fe-silicates, mostly hedenbergite, by pyrrhotite during the early retrograde stage and by pyrite during the later retrograde stage and the hydrothermal stage (Figure 4). The previously published sulfur isotope data show that sulfur is predominantly magmatic in origin [70]. The textural features also point to a slight time lag between intensive degassing of magmatic $\mathrm{CO}_{2}$ and S-bearing volatiles, probably controlled by the difference in solubility of $\mathrm{CO}_{2}$ and $\mathrm{S}$ in silicate melts [71]. 


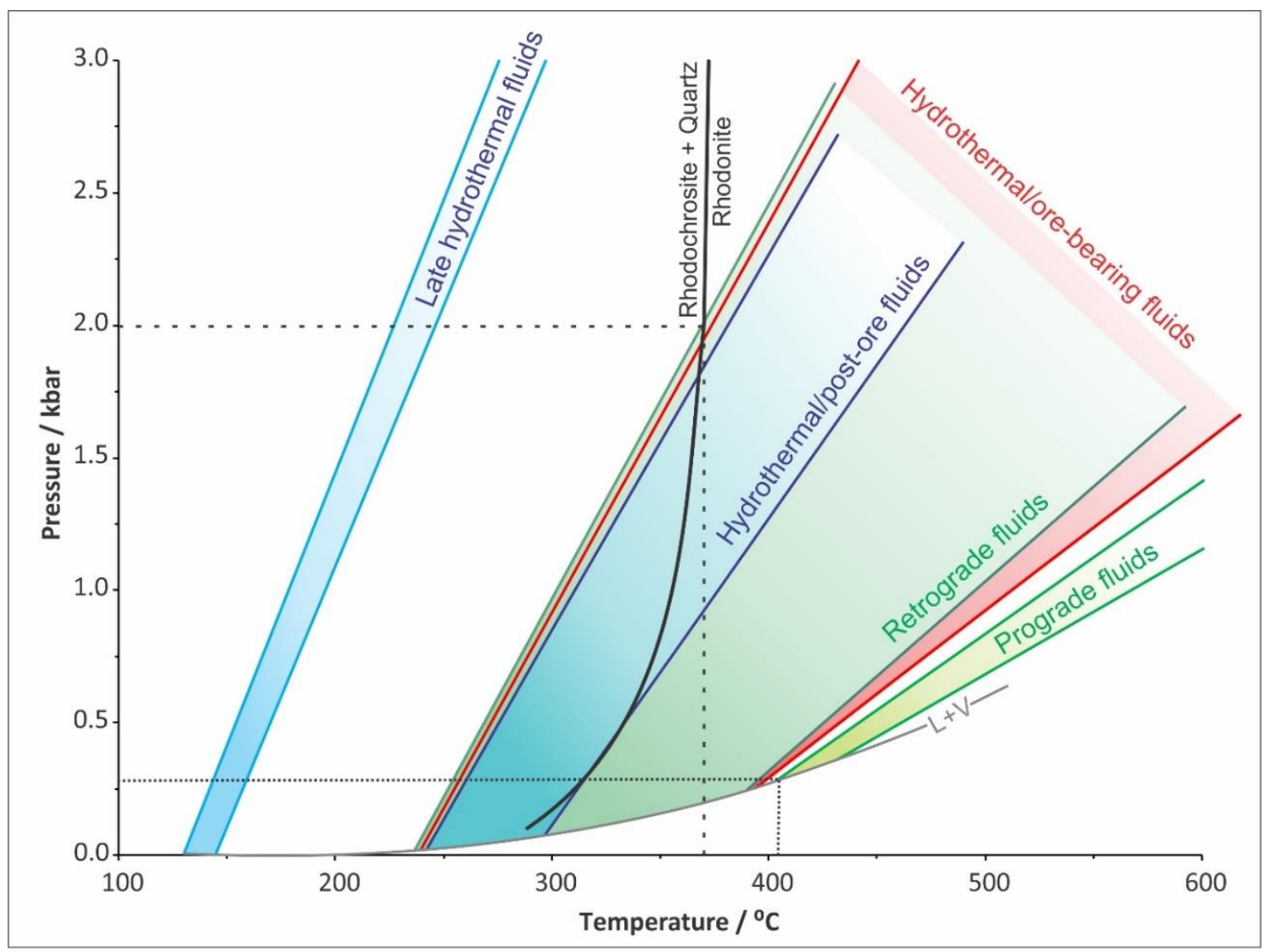

Figure 14. Pressure-temperature (P-T) diagram showing the ranges of isochores obtained from fluid inclusions that host prograde fluids (primary fluid inclusions in pyroxene), retrograde fluids (primary fluid inclusions in retrograde quartz), hydrothermal/ore-bearing fluids (primary fluid inclusions in synore quartz), hydrothermal/post-ore fluids (primary fluid inclusions in post-ore calcite) and a very late hydrothermal (secondary) fluid inclusion in post-ore calcite. The trapping conditions for the retrograde stage are limited by the P-T stability of rhodonite, rhodochrosite and quartz.

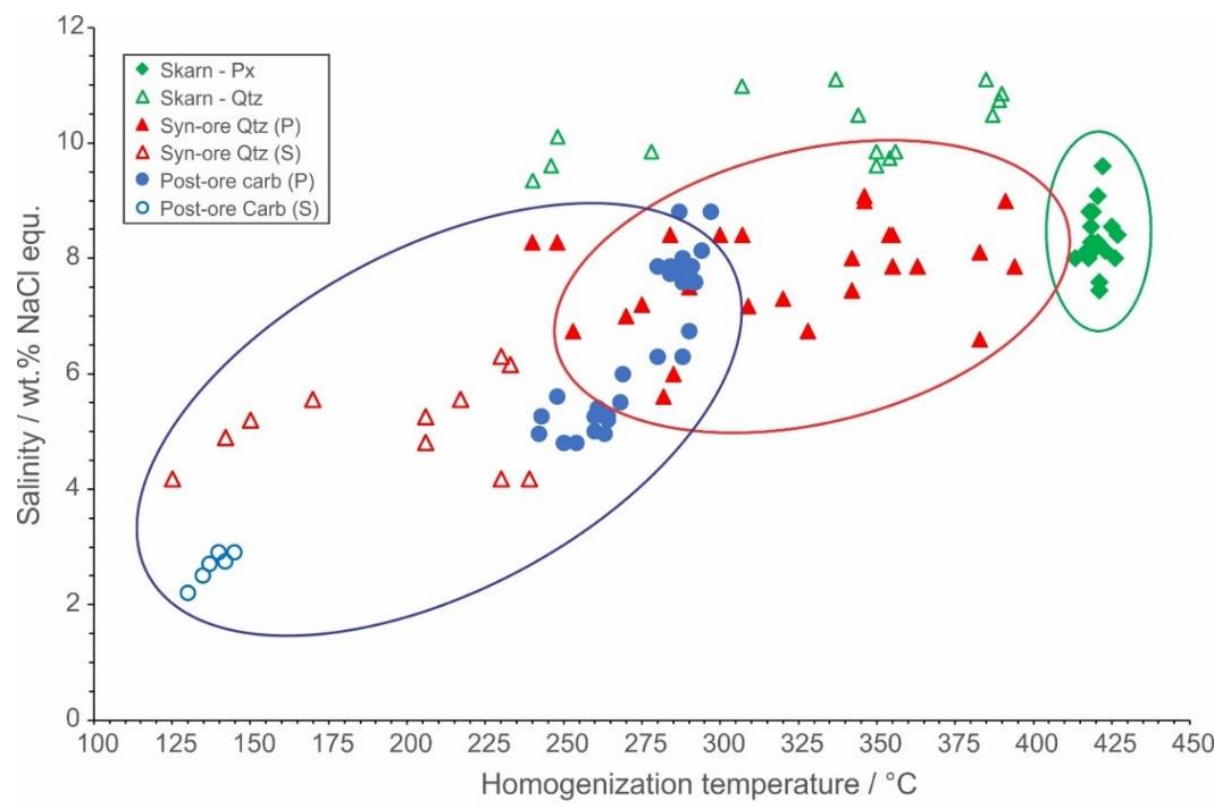

Figure 15. Correlation of homogenization temperature and salinity for fluid inclusions in skarn, syn-ore and post-ore minerals. 
The isotopic composition of hydrothermal carbonates reflects diminishing influence of magmatic $\mathrm{CO}_{2}$ and more significant contribution of the host cipollino marble (Figure 13). The fluid inclusions studies revealed that the syn-ore mineralization was deposited from $\mathrm{Mg}$-Na-chloride or $\mathrm{Fe}^{2+}$-chloride hydrothermal fluids. The wide range of recorded homogenization temperatures, together with the variable salinities (Figure 15), suggest cooling under the influence of cold ground waters as a plausible mechanism for the ore deposition:

$$
\begin{aligned}
& \mathrm{PbCl}_{2}(\mathrm{aq})+\mathrm{H}_{2} \mathrm{~S}(\mathrm{aq}) \oplus \mathrm{PbS}+2 \mathrm{H}^{+}+2 \mathrm{Cl}^{-} \\
& \mathrm{ZnCl}_{2}(\mathrm{aq})+\mathrm{H}_{2} \mathrm{~S}(\mathrm{aq}) \oplus \mathrm{ZnS}+2 \mathrm{H}^{+}+2 \mathrm{Cl}^{-}
\end{aligned}
$$

However, neutralization of the mineralizing fluids in reactions with host carbonates contributed to the ore deposition (Figure 16):

$$
\begin{aligned}
& \mathrm{PbCl}_{2}(\mathrm{aq})+\mathrm{H}_{2} \mathrm{~S}(\mathrm{aq})+2 \mathrm{CaCO}_{3} \boxminus \mathrm{PbS}+2 \mathrm{HCO}_{3}{ }^{-}+2 \mathrm{Ca}^{2+}+2 \mathrm{Cl}^{-} \\
& \mathrm{ZnCl}_{2}(\mathrm{aq})+\mathrm{H}_{2} \mathrm{~S}(\mathrm{aq})+2 \mathrm{CaCO}_{3} \boxminus \mathrm{ZnS}+2 \mathrm{HCO}_{3}{ }^{-}+2 \mathrm{Ca}^{2+}+2 \mathrm{Cl}^{-}
\end{aligned}
$$
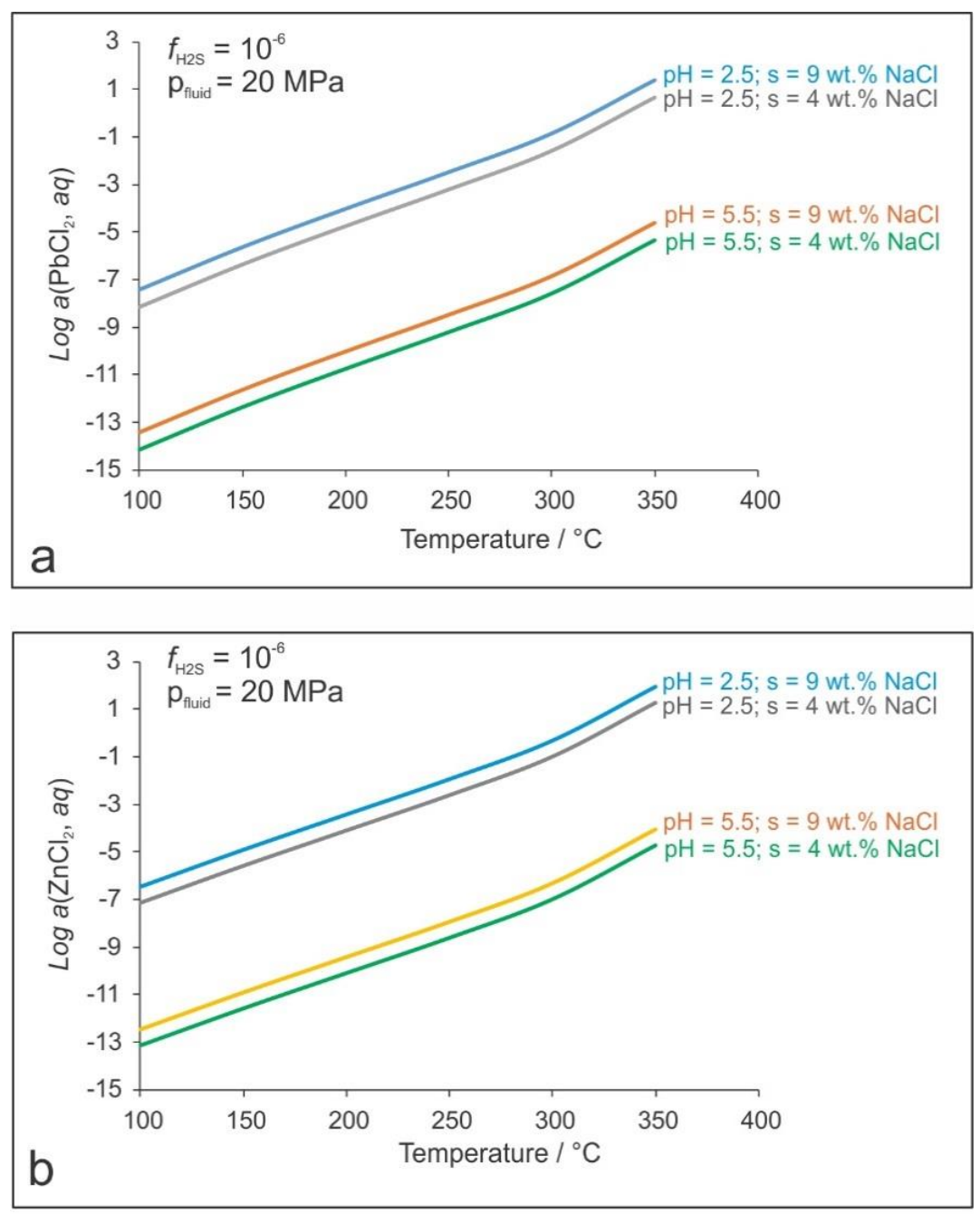

Figure 16. (a) Solubility of $\mathrm{Pb}$ as a function of temperature, $\mathrm{pH}$, and the fluid salinity; (b) Solubility of $\mathrm{Zn}$ as a function of temperature, $\mathrm{pH}$, and the fluid salinity (s). The $\mathrm{H}_{2} \mathrm{~S}$ fugacity $\left(f_{\mathrm{H} 2 \mathrm{~S}}\right)$ has been fixed as $10^{-6}$ and the total pressure ( $\mathrm{p}_{\text {fluid }}$ ) as $20 \mathrm{MPa}$. 
The post-ore stage is marked by the abundant deposition of calcite, revealing near-neutral $\mathrm{pH}$ conditions. The isotopic composition of post-ore carbonates overlaps with the values obtained from syn-ore carbonates (Figure 13). The fluid inclusion data suggest deposition temperatures below $300{ }^{\circ} \mathrm{C}$ from relatively diluted Ca-Na-Cl-bearing fluids.

\section{Comparison with Other Distal Pb-Zn-Ag Skarn Deposits}

The mineralization at the Sasa $\mathrm{Pb}-\mathrm{Zn}-\mathrm{Ag}$ deposit shows many distinctive features typical of base metal skarn deposits including: (1) a carbonate lithology as the main immediate host of the mineralization; (2) a close spatial relation between the mineralization and magmatic bodies of an intermediate composition; (3) a presence of the prograde anhydrous Ca-Fe-Mg-Mn-silicate and the retrograde hydrous $\mathrm{Ca}-\mathrm{Fe}-\mathrm{Mg}-\mathrm{Mn} \pm \mathrm{Al}$-silicate mineral assemblages; (4) a deposition of base metal sulfides, predominately galena and sphalerite, during the hydrothermal stage; and (5) a post-ore stage characterized by the deposition of a large quantity of carbonates $[62,72,73]$.

However, mineralogical, geochemical and isotope characteristics of the Sasa $\mathrm{Pb}-\mathrm{Zn}-\mathrm{Ag}$ deposit differ in some details from similar deposits elsewhere, including the Trepca $\mathrm{Pb}-\mathrm{Zn}-\mathrm{Ag}$ deposit which represents a product of the same magmatic event (Figure 2; [31]):

(1) Although the prograde mineralization of the Sasa $\mathrm{Pb}-\mathrm{Zn}-\mathrm{Ag}$ deposit can be described as a Ca-Fe-Mg-Mn-system, the retrograde mineralization shows a significant hydrothermal input of $\mathrm{Al}$, plausibly reflecting a contribution of the aluminosilicate component within the host cipollino marble.

(2) Prograde skarn mineralization of the great majority of skarn deposits indicates a dominance of high temperature hypersaline magmatic fluids, whereas the later retrograde stage usually reflects mixing with lower temperature and lower salinity fluids of a meteoric origin $[4,62,72$, 73]. However, fluid inclusions and stable isotope data obtained from the retrograde mineral assemblage of the Sasa $\mathrm{Pb}-\mathrm{Zn}-\mathrm{Ag}$ deposit suggest that in this deposit, magmatic fluids played a significant role during the retrograde stage.

(3) The transition from the prograde to the retrograde stage in different skarn deposits can be triggered by various reasons, including brecciation [31] and reactivation of old fractures [62]. In the Sasa Pb-Zn-Ag deposit, the transition was initiated by cooling of the system below $400{ }^{\circ} \mathrm{C}$ and the resulting ductile-to-brittle transition.

\section{Conclusions}

The geological setting of the Sasa Pb-Zn-Ag skarn deposit and previously published geochemical studies on the associated magmatic rocks (trachytic to trachydacitic composition; calc-alkaline character; $\mathrm{Na}_{2} \mathrm{O} / \mathrm{K}_{2} \mathrm{O}<1$; high LILE/HFSE ratios; strong enrichment in $\mathrm{K}, \mathrm{Pb}$ and $\mathrm{U}$; the $\mathrm{K} / \mathrm{Ar}$ age of 31-24 Ma) suggest that the Sasa deposit is a product of the calc-alkaline to shoshonitic post-collisional magmatism that affected the Balkan Peninsula during the Oligocene-Miocene period and resulted in formation of numerous magmatic-hydrothermal ore deposits along the Vardar Zone and the Serbo-Macedonian Massif.

The relatively simple, pyroxene-dominated, prograde mineralization at the Sasa $\mathrm{Pb}-\mathrm{Zn}-\mathrm{Ag}$ skarn deposit resulted from an interaction of magmatic fluids with the host cipollino marble. The absence of direct contacts between the mineralization and the magmatic rocks as well as the textural features of the skarn paragenesis reflect the infiltration-driven metasomatism. Obtained mineralogical and geochemical data suggest that the prograde stage occurred under conditions of low water activity, low oxygen, sulfur and $\mathrm{CO}_{2}$ fugacities and a high $\mathrm{K}^{+} / \mathrm{H}^{+}$molar ratio. Fluid inclusion data set the minimum $\mathrm{P}-\mathrm{T}$ conditions at $30 \mathrm{MPa}$ and approximately $405^{\circ} \mathrm{C}$. Mineralizing fluids were moderately saline and low density $\mathrm{Ca}-\mathrm{Na}$-chloride bearing aqueous solutions.

The transition from the prograde to the retrograde stage was initiated by cooling of the system below $400{ }^{\circ} \mathrm{C}$ and the associated ductile-to-brittle transition that shifted the system from the lithostatic 
to hydrostatic regime. The retrograde mineral assemblages reflect conditions of a high water activity, high oxygen and $\mathrm{CO}_{2}$ fugacities, a gradual increase in the sulfur fugacity and a low $\mathrm{K}^{+} / \mathrm{H}^{+}$molar ratio. The isotopic composition of retrograde carbonates revealed a significant contribution of magmatic $\mathrm{CO}_{2}$. Infiltration fluids carried $\mathrm{MgCl}_{2}$ and had a slightly higher salinity compared to the prograde fluids. The maximum formation conditions are set to $375{ }^{\circ} \mathrm{C}$ and $200 \mathrm{MPa}$.

The deposition of ore minerals (predominantly $\mathrm{Bi}$, In and Ag-enriched galena and $\mathrm{Fe}$ and Mn-bearing sphalerite) occurred during the hydrothermal phase under a diminishing influence of magmatic $\mathrm{CO}_{2}$. The mixing of ore-bearing (Mg-Na-chloride or $\mathrm{Fe}^{2+}$-chloride) aqueous solutions with cold and diluted ground waters is the most plausible reason for the destabilization of metal-chloride complexes. However, neutralization of relatively acidic ore-bearing fluids in the interaction with the host lithology could have significantly contributed to the deposition.

The post-ore, predominantly carbonate, mineralization was deposited from diluted Ca-Na-Cl-bearing fluids of a near-neutral $\mathrm{pH}$ composition. The depositional temperature is estimated to be below $300^{\circ} \mathrm{C}$.

Author Contributions: Conceptualization, S.S.P., Z.P. and L.P.; Data curation, S.S.P., G.T., D.Š., K.R., J.E.S. and K.N.; Formal analysis, D.̌̌., K.R., J.E.S. and K.N.; Funding acquisition, S.S.P. and L.P.; Methodology, S.S.P., J.E.S. and K.N.; Project administration, S.S.P.; Resources, Z.P., G.T. and T.S.; Supervision, S.S.P. and L.P.; Validation, T.S., K.N. and L.P.; Visualization, S.S.P., Z.P., D.Š. and K.R.; Writing-original draft, S.S.P.; Writing-review and editing, Z.P., G.T., T.S., D.Š., K.R., J.E.S., K.N. and L.P.

Funding: The early stages of this study were conducted as a part of the project "Geochemical characteristics of hydrothermal ore deposits in the Republic of Macedonia" funded by Croatian Ministry of Science, Education and Sport and Macedonian Ministry of Science. The final part of the study was funded by the project A31566 at UiT The Arctic University of Norway.

Acknowledgments: We would like to thank the staff at the Sasa mine, Makedonska Kamenica, for all their support during the multiple sampling campaigns. Matteus Lindgren is greatly appreciated for help in obtaining the stable isotope data. A special thank goes to Vasilios Melfos and Panagiotis Voudouris for handling the manuscript as well as to three anonymous reviewers whose comments substantially improved the manuscript.

Conflicts of Interest: The authors declare no conflict of interest.

\section{References}

1. Meinert, L.D.; Hedenquist, J.W.; Satoh, H.; Matsuhisa, Y. Formation of anhydrous and hydrous skarn in $\mathrm{Cu}-\mathrm{Au}$ ore deposits by magmatic fluids. Econ. Geol. 2003, 98, 147-156. Available online: https://pubs.geoscienceworld.org/segweb/economicgeology/article-abstract/98/1/ 147/22314/formation-of-anhydrous-and-hydrous-skarn-in-cu-au?redirectedFrom=fulltext (accessed on 28 September 2018). [CrossRef]

2. Baker, T.; Van Achterberg, E.; Ryan, C.G.; Lang, J.R. Composition and evolution of ore fluids in a magmatic-hydrothermal skarn deposit. Geology 2004, 32, 117-120. Available online: https:/ / pubs.geoscienceworld.org/gsa/geology/article-abstract/32/2/117/103697/compositionand-evolution-of-ore-fluids-in-a?redirectedFrom $=$ fulltext (accessed on 28 September 2018). [CrossRef]

3. Shu, Q.; Lai, Y.; Sun, Y.; Wang, C.; Meng, S. Ore genesis and hydrothermal evolution of the Baiyinnuo'er zinc-lead skarn deposit, northeast China: Evidence from isotopes $(\mathrm{S}, \mathrm{Pb})$ and fluid inclusions. Econ. Geol. 2013, 108, 835-860. Available online: https:/ / pubs.geoscienceworld.org/segweb/economicgeology/articleabstract/108/4/835/128539/ore-genesis-and-hydrothermal-evolution-of-the?redirectedFrom=fulltext (accessed on 28 September 2018). [CrossRef]

4. Strmić Palinkaš, S.; Palinkaš, L.A.; Mandić, M.; Roller-Lutz, Z.; Pécskay, Z.; Maliqi, G.; Bermanec, V. Origin and K-Ar age of the phreatomagmatic breccia at the Trepča Pb-Zn-Ag skarn deposit, Kosovo: Implications for ore-forming processes. Geol. Croat. 2016, 69, 121-142. Available online: http:/ /www.geologia-croatica. hr/ojs/index.php/GC/article/view/GC.2016.10 (accessed on 28 September 2018). [CrossRef]

5. Janković, S. Types of copper deposits related to volcanic environment in the Bor district, Yugoslavia. Geol. Rundsch. 1990, 79, 467-478. Available online: https:/ /link.springer.com/article/10.1007/BF01830639 (accessed on 28 September 2018). [CrossRef] 
6. Janković, S. The Carpatho-Balkanides and adjacent area: A sector of the Tethyan Eurasian metallogenic belt. Miner. Depos. 1997, 32, 426-433. Available online: https://link.springer.com/article/10.1007/s001260050110 (accessed on 28 September 2018). [CrossRef]

7. Heinrich, C.A.; Neubauer, F. Cu-Au-Pb-Zn-Ag metallogeny of the Alpine-Balkan-Carpathian-Dinaride geodynamic province. Miner. Depos. 2002, 37, 533-540. Available online: https:/ /link.springer.com/article/ 10.1007\%2Fs00126-002-0271-x (accessed on 28 September 2018). [CrossRef]

8. Lehmann, S.; Barcikowski, J.; von Quadt, A.; Gallhofer, D.; Peytcheva, I.; Heinrich, C.A.; Serafimovski, T. Geochronology, geochemistry and isotope tracing of the Oligocene magmatism of the Buchim-Damjan-Borov Dol ore district: Implications for timing, duration and source of the magmatism. Lithos 2013, 180, 216-233. Available online: https://www.sciencedirect.com/science/article/pii/S0024493713002909 (accessed on 28 September 2018). [CrossRef]

9. Kroll, T.; Müller, D.; Seifert, T.; Herzig, P.M.; Schneider, A. Petrology and geochemistry of the shoshonite-hosted Skouries porphyry Cu-Au deposit, Chalkidiki, Greece. Miner. Depos. 2002, 37, 137-144. Available online: https:/ / link.springer.com/article/10.1007/s00 (accessed on 28 September 2018). [CrossRef]

10. Janković, S.; Serafimovski, T.; Aleksandrov, M. The Besna Kobila-Osogovo metallogenic zone. Geol. Maced. $1995,9,39-50$.

11. Peltekovski, Z. Modeling of Mining Reserves in Svinja Reka Deposit Sasa. Master Thesis, University Goce Delcev, Štip, Republic of Macedonia, 2012. (In Macedonian)

12. Sijakova-Ivanova, T.; Boev, B.; Mircovski, V. Metamorphism of the skarn rocks from the Sasa ore field. Geol. Maced. 2012, 26, 65-70. Available online: http://js.ugd.edu.mk/index.php/GEOLMAC/article/view/651 (accessed on 28 September 2018).

13. Dimitrijevic, M.D. Dinarides and the Vardar Zone: A short review of the geology. Acta Vulcanologica 2001, 13, 1000-1008. Available online: https:/ / eurekamag.com/research/018/743/018743766.php (accessed on 28 September 2018).

14. Karamata, S. The geological development of the Balkan Peninsula related to the approach, collision and compression of Gondwanan and Eurasian units. Geol. Soc. Lond. Spec. Publ. 2006, 260, 155-178. Available online: http:/ / sp.lyellcollection.org/content/260/1/155 (accessed on 28 September 2018). [CrossRef]

15. Meinhold, G.; Kostopoulos, D.; Frei, D.; Himmerkus, F.; Reischmann, T. U-Pb LA-SF-ICP-MS zircon geochronology of the Serbo-Macedonian Massif, Greece: Palaeotectonic constraints for Gondwana-derived terranes in the Eastern Mediterranean. Int. J. Earth. Sci. 2010, 99, 813-832. [CrossRef]

16. Antić, M.D.; Kounov, A.; Trivić, B.; Spikings, R.; Wetzel, A. Evidence of Variscan and Alpine tectonics in the structural and thermochronological record of the central Serbo-Macedonian Massif (south-eastern Serbia). Int. J. Earth. Sci. 2017, 106, 1665-1692. Available online: https:/ /link.springer.com/article/10.1007/s00531016-1380-6 (accessed on 28 September 2018). [CrossRef]

17. Antić, M.D.; Kounov, A.; Trivić, B.; Wetzel, A.; Peytcheva, I.; von Quadt, A. Alpine thermal events in the central Serbo-Macedonian Massif (southeastern Serbia). Int. J. Earth. Sci. 2016, 105, 1485-1505. Available online: https:/ /link.springer.com/article/10.1007/s00531-015-1266-z (accessed on 28 September 2018). [CrossRef]

18. Antić, M.; Peytcheva, I.; von Quadt, A.; Kounov, A.; Trivić, B.; Serafimovski, T.; Tasev, G.; Gerdjikov, I.; Wetzel, A. Pre-Alpine evolution of a segment of the North Gondwanan margin: Geochronological and geochemical evidence from the central Serbo-Macedonian Massif. Gondwana Res. 2016, 19, 523-544. Available online: https://www.sciencedirect.com/science/article/pii/S1342937X15002051 (accessed on 28 September 2018). [CrossRef]

19. Zagorčev, I.S.; Bončeva, I. Indications of Devonian basic volcanism in Southwest Bulgaria. Geol. Balcanica 1988, 18, 55-63.

20. Vasković, N. Petrology and P-T condition of white mica-chlorite schists from Vlasina series-Surdulica, SE Serbia. Ann. Geol. Penins. Balk. 2002, 64, 199-220. Available online: https://www.ingentaconnect.com/ content/doaj/03500608/2002/00002002/00000064/art00013 (accessed on 28 September 2018). [CrossRef]

21. Cvetković, V.; Prelević, D.; Downes, H.; Jovanović, M.; Vaselli, O.; Pécskay, Z. Origin and geodynamic significance of Tertiary postcollisional basaltic magmatism in Serbia (central Balkan Peninsula). Lithos 2004, 73, 161-186. Available online: https://www.sciencedirect.com/science/article/pii/S0024493703002408 (accessed on 28 September 2018). [CrossRef] 
22. Prelević, D.; Foley, S.F.; Romer, R.L.; Cvetković, V.; Downes, H. Tertiary ultrapotassic volcanism in Serbia: Constraints on petrogenesis and mantle source characteristics. J. Petrol. 2005, 46, 1443-1487. Available online: https:/ /academic.oup.com/petrology/article/46/7/1443/1546674 (accessed on 28 September 2018). [CrossRef]

23. Borojević Šoštarić, S.; Cvetković, V.; Neubauer, F.; Palinkaš, L.A.; Bernroider, M.; Genser, J. Oligocene shoshonitic rocks of the Rogozna Mts.(Central Balkan Peninsula): Evidence of petrogenetic links to the formation of $\mathrm{Pb}-\mathrm{Zn}-\mathrm{Ag}$ ore deposits. Lithos 2012, 148, 176-195. Available online: https:/ / www.sciencedirect. com/science/article/pii/S0024493712002204 (accessed on 28 September 2018). [CrossRef]

24. Melfos, V.; Voudouris, P. Cenozoic metallogeny of Greece and potential for precious, critical and rare metals exploration. Ore Geol. Rev. 2017, 89, 1030-1057. Available online: https:/ /www.sciencedirect.com/science/ article/pii/S0169136816304206 (accessed on 28 September 2018). [CrossRef]

25. Lips, A.L.; Herrington, R.J.; Stein, G.; Kozelj, D.; Popov, K.; Wijbrans, J.R. Refined timing of porphyry copper formation in the Serbian and Bulgarian portions of the Cretaceous Carpatho-Balkan Belt. Econ. Geol. 2004, 99, 601-609. Available online: https:/ / pubs.geoscienceworld.org/segweb/economicgeology / article-abstract/ 99/3/601/22445/refined-timing-of-porphyry-copper-formation-in-the?redirectedFrom=fulltext (accessed on 28 September 2018). [CrossRef]

26. Serafimovski, T.; Stefanova, V.; Volkov, A.V. Dwarf copper-gold porphyry deposits of the Buchim-Damjan-Borov Dol ore district, Republic of Macedonia (FYROM). Geol. Ore Deposits 2010, 52, 179-195. Available online: https:/ /link.springer.com/content/pdf/10.11342FS1075701510030013 (accessed on 10 October 2018). [CrossRef]

27. Serafimovski, T.; Tasev, G.; Strmić Palinkaš, S.; Palinkaš, L.A.; Gjorgjiev, L. Porphyry Cu mineralizations related with the small Tertiary volcanic intrusions in the Bučim ore deposit, Eastern Macedonia. Geol. Croat. 2016, 69, 101-119. Available online: https:/ /hrcak.srce.hr/155678 (accessed on 28 September 2018). [CrossRef]

28. Lips, A.L. Correlating magmatic-hydrothermal ore deposit formation over time with geodynamic processes in SE Europe. Geol. Soc. Lond. Spec. Publ. 2002, 204, 69-79. Available online: http://sp.lyellcollection.org/ content/specpubgsl/204/1/69 (accessed on 10 October 2018). [CrossRef]

29. Neubauer, F. Contrasting late cretaceous with neogene ore provinces in the Alpine-Balkan-Carpathian-Dinaride collision belt. Geol. Soc. Lond. Spec. Publ. 2002, 204, 81-102. Available online: http://sp.lyellcollection.org/content/204/1/81 (accessed on 28 September 2018). [CrossRef]

30. Radosavljević, S.A.; Stojanović, J.N.; Radosavljević-Mihajlović, A.S.; Vuković, N.S. (Pb-Sb)-bearing sphalerite from the Čumavići polymetallic ore deposit, Podrinje Metallogenic District, East Bosnia and Herzegovina. Ore Geol. Rev. 2016, 72, 253-268. Available online: https://www.sciencedirect.com/science/article/pii/ S0169136815001857 (accessed on 28 September 2018). [CrossRef]

31. Strmić Palinkaš, S.; Palinkaš, L.A.; Renac, C.; Spangenberg, J.E.; Lüders, V.; Molnar, F.; Maliqi, G. Metallogenic model of the Trepča Pb-Zn-Ag Skarn Deposit, Kosovo: Evidence from fluid inclusions, rare earth elements, and stable isotope data. Econ. Geol. 2013, 108, 135-162. Available online: https:/ / pubs.geoscienceworld.org/segweb/economicgeology/article/108/1/135/128446/ metallogenic-model-of-the-trepca-pb-zn-ag-skarn (accessed on 28 September 2018). [CrossRef]

32. Borojević Šoštarić, S.; Palinkaš, L.A.; Neubauer, F.; Hurai, V.; Cvetkovic, V.; Roller-Lutz, Z.; Mandić, M.; Genser, J. Silver-base metal epithermal vein and listwanite hosted deposit Crnac, Rogozna Mts., Kosovo, part II: A link between magmatic rocks and epithermal mineralization. Ore Geol. Rev. 2013, 50, 98-117. Available online: https:/ / www.sciencedirect.com/science/article/pii/S0169136812002120 (accessed on 28 September 2018). [CrossRef]

33. Veselinovic-Williams, M. Characteristics and Origin of Polymetallic Mineralisation in the Kopaonik Region of Serbia and Kosovo, with Particular Reference to the Belo Brdo Pb-Zn (Ag) Deposit. Ph.D. Thesis, Kingston University, London, UK, 2011.

34. Serafimovski, T.; Tasev, G. Sulfur isotope composition of some polymetallic deposits in the Republic of Macedonia. Geol. Maced. 2005, 19, 1-11. Available online: http:// eprints.ugd.edu.mk/1557/ (accessed on 28 September 2018).

35. Kalogeropoulos, S.I.; Kilias, S.P.; Bitzios, D.C.; Nicolaou, M.; Both, R.A. Genesis of the Olympias carbonate-hosted $\mathrm{Pb}-\mathrm{Zn}(\mathrm{Au}, \mathrm{Ag})$ sulfide ore deposit, eastern Chalkidiki Peninsula, northern Greece. Econ. 
Geol. 1989, 84, 1210-1234. Available online: https://pubs.geoscienceworld.org/segweb/economicgeology/ article-abstract/84/5/1210/20675/genesis-of-the-olympias-carbonate-hosted-pb-zn-au?redirectedFrom= fulltext (accessed on 28 September 2018). [CrossRef]

36. Clark, A.H.; Ullrich, T.D. 40 Ar-39 Ar age data for andesitic magmatism and hydrothermal activity in the Timok Massif, eastern Serbia: Implications for metallogenetic relationships in the Bor copper-gold subprovince. Miner. Depos. 2004, 39, 256-262. Available online: https:/ /link.springer.com/article/10.1007/ s00126-003-0370-3 (accessed on 28 September 2018). [CrossRef]

37. Frei, R. Evolution of mineralizing fluid in the porphyry copper system of the Skouries Deposit, Northeast Chalkidiki (Greece); evidence from combined $\mathrm{Pb}-\mathrm{Sr}$ and stable isotope data. Econ. Geol. 1995, 90, 746-762. Available online: https:/ / pubs.geoscienceworld.org/segweb/economicgeology/article-abstract/ 90/4/746/21443/evolution-of-mineralizing-fluid-in-the-porphyry?redirectedFrom=fulltext (accessed on 28 September 2018). [CrossRef]

38. Tasev, G.; Serafimovski, T.; Lazarov, P. New K-Ar, ${ }^{87} \mathrm{Sr} /{ }^{86} \mathrm{Sr}, \mathrm{REE}$, and XRF data for Tertiary volcanic rocks in the Sasa-Toranica ore district, Macedonia. In Mineral Deposit Research: Meeting the Global Challenge; Mao, J., Bierlein, F.P., Eds.; Springer: Berlin/Heidelberg, Germany, 2005; pp. 837-840.

39. Aleksandrov, M. Metalogenetske karakteristike polimetalicnog rudnog polja Sase-lstocna Makedonija. Ph.D. Thesis, University of Belgrade, Belgrade, Serbia, 1992. (In Serbian)

40. Serafimovski, T. Metallogeny of the Lece-Chalkidiki Zone. Ph.D. Thesis, University Goce Delcev, Štip, Republic of Macedonia, 1990. (In Macedonian)

41. Marchev, P.; Raicheva, R.; Downes, H.; Vaselli, O.; Chiaradia, M.; Moritz, R. Compositional diversity of Eocene-Oligocene basaltic magmatism in the Eastern Rhodopes, SE Bulgaria: Implications for genesis and tectonic setting. Tectonophysics 2004, 393, 301-328. Available online: https:/ / www.sciencedirect.com/ science/article/pii/S0040195104002823 (accessed on 28 September 2018). [CrossRef]

42. Goldstein, R.H.; Reynolds, T.J. Systematics of Fluid Inclusions in Diagenetic Minerals; SEPM Society for Sedimentary Geology: Tulsa, OK, USA, 1994; p. 199.

43. Goldstein, R.H. Fluid inclusions in sedimentary and diagenetic systems. Lithos 2001, 55, 159-193. Available online: https://www.sciencedirect.com/science/article/pii/S002449370000044X?via\%3Dihub (accessed on 28 September 2018). [CrossRef]

44. Bodnar, R.J. Introduction to Fluid Inclusions; Mineralogical Association of Canada: Quebec, QC, Canada, 2003; pp. 1-8.

45. Meinert, L.D.; Dipple, G.M.; Nicolescu, G.M. World Skarn Deposits. In Economic Geology 100th Anniversary Volume; Hedenquist, J.W., Thompson, J.F.H., Goldfarb, R.J., Richards, J.P., Eds.; Elsevier: Amsterdan, The Netherlands, 2005; pp. 299-336.

46. Wang, L.; Tang, J.; Bagas, L.; Wang, Y.; Lin, X.; Li, Z.; Li, Y. Early Eocene Longmala skarn Pb-Zn-Cu deposit in Tibet, China: Geochemistry, fluid inclusions, and HOS-Pb isotopic compositions. Ore Geol. Rev. 2017, 88, 99-115. Available online: https:/ / www.sciencedirect.com/science/article/pii/S0169136817300215?via\% 3Dihub (accessed on 28 September 2018). [CrossRef]

47. Soloviev, S.G.; Kryazhev, S.G.; Dvurechenskaya, S.S. Geology, mineralization, stable isotope, and fluid inclusion characteristics of the Vostok-2 reduced W-Cu skarn and Au-W-Bi-As stockwork deposit, Sikhote-Alin, Russia. Ore Geol. Rev. 2017, 86, 338-365. Available online: https://www.sciencedirect. com/science/article/pii/S0169136816302591 (accessed on 28 September 2018). [CrossRef]

48. Ciobanu, C.L.; Cook, N.J. Skarn textures and a case study: The Ocna de Fier-Dognecea orefield, Banat, Romania. Ore Geol. Rev. 2004, 24, 315-370. Available online: https://www.sciencedirect.com/science/ article/pii/S0169136803000593 (accessed on 28 September 2018). [CrossRef]

49. Borisenko, A.S. Cryometric technique applied to studies of the saline composition of solution in gaseous fluid inclusions in minerals. Geol. Geofiz. 1997, 8, 16-27.

50. Bodnar, R.J. Revised equation and table for determining the freezing point depression of $\mathrm{H}_{2} \mathrm{O}-\mathrm{NaCl}$ solutions. Geochim. Cosmochim. Acta 1993, 57, 683-684. Available online: https:/ /www.sciencedirect.com/science/ article/pii/001670379390378A?via\%3Dihub (accessed on 28 September 2018). [CrossRef]

51. Veizer, J.; Hoefs, J. The nature of $\mathrm{O}^{18} / \mathrm{O}^{16}$ and $\mathrm{C}^{13} / \mathrm{C}^{12}$ secular trends in sedimentary carbonate rocks. Geochim. Cosmochim. Acta 1976, 40, 1387-1395. Available online: https:/ /www.sciencedirect.com/science/ article/pii/0016703776901290 (accessed on 10 October 2018). [CrossRef] 
52. Taylor, H.P.; Frechen, J.; Degens, E.T. Oxygen and carbon isotope studies of carbonatites from the Laacher See District, west Germany and the Alno District, Sweden. Geochim. Cosmochim. Acta 1967, 31, 407-430. Available online: https://www.sciencedirect.com/science/article/pii/0016703767900518 (accessed on 10 November 2018). [CrossRef]

53. Serafimovski, T.; Tasev, G.; Dolenec, T. Petrological and geochemical features of the Neogene volcanites of the Osogovo mountains, eastern Macedonia. RMZ Mater. Geoenviron. 2006, 52, 523-534. Available online: http:/ / www.rmz-mg.com/letniki/rmz52/rmz52_0523-0534.pdf (accessed on 28 September 2018).

54. Strmić Palinkaš, S.; Hofstra, A.H.; Percival, T.J.; Borojević Šoštarić, S.; Palinkaš, L.; Bermanec, V.; Boev, B.; Pécskay, Z. Comparison of the Allchar Au-As-Sb-Tl Deposit, Republic of Macedonia, with Carlin-Type Gold Deposits. In Diversity of Carlin-Style Gold Deposits; Muntean, J.L., Ed.; Society of Economic Geologists: Littleton, CO, USA, 2018; pp. 335-363.

55. Meinert, L.D. Skarns and skarn deposits. Geosci. Can. 1992, 19, 145-162. Available online: https://journals. lib.unb.ca/index.php/GC/article/view/3773/0 (accessed on 28 September 2018). [CrossRef]

56. Jansson, N.F.; Allen, R.L. Multistage ore formation at the Ryllshyttan marble and skarn-hosted $\mathrm{Zn}-\mathrm{Pb}-\mathrm{Ag}-(\mathrm{Cu})+$ magnetite deposit, Bergslagen, Sweden. Ore Geol. Rev. 2015, 69, 217-242. Available online: https:/ / www.sciencedirect.com/science/article/pii/S016913681500061X?via\%3Dihub (accessed on 28 September 2018). [CrossRef]

57. Gustafson, W.I. The stability of andradite, hedenbergite, and related minerals in the system Ca-Fe-Si-O-H. J. Petrol. 1974, 15, 455-496. Available online: https:/ /academic.oup.com/petrology/article-abstract/15/3/ 455/1441509?redirectedFrom=fulltext (accessed on 28 September 2018). [CrossRef]

58. Sijakova-Ivanova, T.; Boev, B. Mineralogical characteristics of johannsenite in the Sasa ore field. Geol. Maced. 1997, 11, 45-49. Available online: http:/ / eprints.ugd.edu.mk/2977/ (accessed on 28 September 2018).

59. Helgeson, H.C.; Delany, J.M.; Nesbitt, H.W.; Bird, D.K. Summary and critique of the thermodynamic properties of rock-forming minerals. Am. J. Sci. 1978, 278, 1-229.

60. Angel, R.J. The experimental determination of the johannsenite-bustamite equilibrium inversion boundary. Contrib. Mineral. Petr. 1984, 85, 272-278. Available online: https://link.springer.com/article/10.1007/ BF00378105 (accessed on 28 September 2018). [CrossRef]

61. Kerrick, D.M. The genesis of zoned skarns in the Sierra Nevada, California. J. Petrol. 1971, 18, 144-181. Available online: https://academic.oup.com/petrology/article-abstract/18/1/144/1514509? redirectedFrom=fulltext (accessed on 28 September 2018). [CrossRef]

62. Logan, M.A.V. Mineralogy and geochemistry of the Gualilán skarn deposit in the Precordillera of western Argentina. Ore Geol. Rev. 2000, 17, 113-138. Available online: https://www.sciencedirect.com/science/ article/pii/S0169136800000093 (accessed on 28 September 2018). [CrossRef]

63. Canet, C.; González-Partida, E.; Camprubí, A.; Castro-Mora, J.; Romero, F.M.; Prol-Ledesma, R.M.; Linares, C.; Romero-Guadarrama, J.A.; Sánchez-Vargas, L.I. The Zn-Pb-Ag skarns of Zacatepec, northeastern Oaxaca, Mexico: A study of mineral assemblages and ore-forming fluids. Ore Geol. Rev. 2001, 39, 277-290. Available online: https:/ / www.sciencedirect.com/science/article/pii/S0169136811000357 (accessed on 28 September 2018). [CrossRef]

64. Seward, T.M.; Williams-Jones, A.E.; Migdisov, A.A. The chemistry of metal transport and deposition by ore-forming hydrothermal fluids. In Treatise on Geochemistry, 2nd ed.; Holland, H., Turekian, K., Eds.; Elsevier: Amsterdam, The Netherlands, 2014; Volume 13, pp. 29-57.

65. Fournier, R.O.; Potter, R.W. An equation correlating the solubility of quartz in water from $25{ }^{\circ} \mathrm{C}$ to 900 ${ }^{\circ} \mathrm{C}$ at pressures up to 10,000 bars. Geochim. Cosmochim. Acta 1982, 46, 1969-1973. Available online: https:/ / www.sciencedirect.com/science/article/pii/ 0016703782901351 (accessed on 28 September 2018). [CrossRef]

66. Fournier, R.O. Hydrothermal processes related to movement of fluid from plastic into brittle rock in the magmatic-epithermal environment. Econ. Geol. 1999, 94, 1193-1211. Available online: https:/ / pubs.geoscienceworld.org/segweb/economicgeology/article-abstract/94/8/1193/21899/ hydrothermal-processes-related-to-movement-of?redirectedFrom=fulltext (accessed on 28 September 2018). [CrossRef] 
67. Strmić Palinkaš, S.; Wegner, R.; Čobić, A.; Palinkaš, L.A.; Barreto, S.D.B.; Váczi, T.; Bermanec, V. The role of magmatic and hydrothermal processes in the evolution of Be-bearing pegmatites: Evidence from beryl and its breakdown products. Am. Mineral. 2014, 99, 424-432. Available online: https:/ / pubs.geoscienceworld.org/msa/ammin/article-abstract/99/2-3/424/46089/the-role-ofmagmatic-and-hydrothermal-processes-in?redirectedFrom=fulltext (accessed on 28 September 2018). [CrossRef]

68. Webster, J.D.; Vetere, F.; Botcharnikov, R.E.; Goldoff, B.; McBirney, A.; Doherty, A.L. Experimental and modeled chlorine solubilities in aluminosilicate melts at 1 to 7000 bars and 700 to 1250 ${ }^{\circ} \mathrm{C}$ : Applications to magmas of Augustine Volcano, Alaska. Am. Mineral. 2015, 100, 522-535. Available online: https://pubs.geoscienceworld.org/msa/ammin/article-abstract/100/23/522/40399/experimental-and-modeled-chlorine-solubilities-in?redirectedFrom=fulltext (accessed on 28 September 2018). [CrossRef]

69. Botcharnikov, R.E.; Holtz, F.; Behrens, H. Solubility and fluid-melt partitioning of $\mathrm{H} 2 \mathrm{O}$ and $\mathrm{Cl}$ in andesitic magmas as a function of pressure between 50 and $500 \mathrm{MPa}$. Chem. Geol. 2015, 418, 117-131. Available online: https:/ / www.sciencedirect.com/science/article/pii/S0009254115003381 (accessed on 28 September 2018). [CrossRef]

70. Serafimovski, T.; Tasev, G. Sulfur isotope study of sulfides from some mineral deposits from the Lece-Chalkidiki metallogenic zone. In Proceedings of the 2006 National Conference With International Participation Publishing House Bulgarian Geological Society, Sofia, Bulgaria, 30 November-1 December 2006; pp. 251-254.

71. Burgisser, A.; Alletti, M.; Scaillet, B. Simulating the behavior of volatiles belonging to the C-O-H-S system in silicate melts under magmatic conditions with the software D-Compress. Comput. Geosci. 2015, 79, 1-14. Available online: https://www.sciencedirect.com/science/article/pii/S0098300415000503 (accessed on 28 September 2018). [CrossRef]

72. Samson, I.M.; Williams-Jones, A.E.; Ault, K.M.; Gagnon, J.E.; Fryer, B.J. Source of fluids forming distal $\mathrm{Zn}-\mathrm{Pb}-\mathrm{Ag}$ skarns: Evidence from laser ablation-inductively coupled plasma-mass spectrometry analysis of fluid inclusions from El Mochito, Honduras. Geology 2008, 36, 947-950. Available online: https:/ / pubs.geoscienceworld.org/gsa/geology/article/36/12/947/29724/source-offluids-forming-distal-zn-pb-ag-skarns (accessed on 10 October 2018). [CrossRef]

73. Yang, Y.L.; Ye, L.; Bao, T.; Gao, W.; Li, Z.L. Mineralization of Luziyuan Pb-Zn skarn deposit, Baoshan, Yunnan Province, SW China: Evidence from petrography, fluid inclusions and stable isotopes. Geol. Mag. 2018, 1-20. Available online: https://www.cambridge.org/core/journals/geological-magazine/article/ mineralization-of-luziyuan-pbzn-skarn-deposit-baoshan-yunnan-province-sw-china-evidence-frompetrography-fluid-inclusions-and-stableisotopes/E549FFF8C9B403F9FF6F6CBE33573D43 (accessed on 10 October 2018). [CrossRef]

(C) 2018 by the authors. Licensee MDPI, Basel, Switzerland. This article is an open access article distributed under the terms and conditions of the Creative Commons Attribution (CC BY) license (http://creativecommons.org/licenses/by/4.0/). 